\title{
Vitamin D and Inflammatory Bowel Disease
}

\author{
Marco Ardesia, ${ }^{1}$ Guido Ferlazzo, ${ }^{2}$ and Walter Fries ${ }^{3}$ \\ ${ }^{1}$ Internal Medicine, Department of Clinical and Experimental Medicine, University of Messina, Messina, Italy \\ ${ }^{2}$ Laboratory of Immunology and Biotherapy, Department of Human Pathology, University of Messina, Messina, Italy \\ ${ }^{3}$ Clinical Unit for Chronic Bowel Disorders, IBD-UNIT, Department of Clinical and Experimental Medicine, University of Messina, \\ Via Consolare Valeria 1, 98125 Messina, Italy \\ Correspondence should be addressed to Walter Fries; fwalter@unime.it
}

Received 27 November 2014; Revised 2 February 2015; Accepted 13 February 2015

Academic Editor: K. Šebeková

Copyright (C) 2015 Marco Ardesia et al. This is an open access article distributed under the Creative Commons Attribution License, which permits unrestricted use, distribution, and reproduction in any medium, provided the original work is properly cited.

Vitamin D deficiency has been recognized as an environmental risk factor for Crohn's disease since the early 80s. Initially, this finding was correlated with metabolic bone disease. Low serum 25-hydroxyvitamin D levels have been repeatedly reported in inflammatory bowel diseases together with a relationship between vitamin D status and disease activity. Subsequently, low serum vitamin $\mathrm{D}$ levels have been reported in various immune-related diseases pointing to an immunoregulatory role. Indeed, vitamin $\mathrm{D}$ and its receptor (VDR) are known to interact with different players of the immune homeostasis by controlling cell proliferation, antigen receptor signalling, and intestinal barrier function. Moreover, 1,25-dihydroxyvitamin D is implicated in NOD2-mediated expression of defensin- $\beta 2$, the latter known to play a crucial role in the pathogenesis of Crohn's disease (IBD1 gene), and several genetic variants of the vitamin D receptor have been identified as Crohn's disease candidate susceptibility genes. From animal models we have learned that deletion of the VDR gene was associated with a more severe disease. There is a growing body of evidence concerning the therapeutic role of vitamin $\mathrm{D} /$ synthetic vitamin $\mathrm{D}$ receptor agonists in clinical and experimental models of inflammatory bowel disease far beyond the role of calcium homeostasis and bone metabolism.

\section{Introduction}

Vitamin $\mathrm{D}$ is a fat-soluble vitamin whose active form, calcitriol or 1,25-dihydroxyvitamin $\mathrm{D}_{3}\left(1,25(\mathrm{OH})_{2} \mathrm{D}_{3}\right)$, regulates bone, calcium, and phosphorus metabolism [1]. However, vitamin $\mathrm{D}$ also influences immune system function, and deficiency has been recognized as an environmental risk factor for autoimmune diseases like Crohn's disease (CD) [2].

In humans, vitamin $\mathrm{D}$ may be obtained from two sources: diet (as fat-soluble vitamin) and by ultraviolet- (UV-) mediated synthesis in the epidermal layer of the skin where UVrays promote photolytic cleavage of 7-dihydrocholesterol (7HDC) into vitamin $\mathrm{D}_{3}$ [3]. The latter is the most important source of this metabolite and, at this point, vitamin D can be considered as a hormone [4]. After production, vitamin $\mathrm{D}$ is activated by a two-step hydroxylation, first in the carbon 5 -position by 25 -hydroxylase in the liver then by $1 \alpha$ hydroxylase in the kidney: this active metabolite exerts its functions by interacting with the vitamin D receptor (VDR), a receptor that belongs to the superfamily of nuclear hormone receptors [1]. Binding to VDR leads to the transcription of several vitamin D-response genes, located on single loci [5]. Various tissues and, especially, immune-related cells express VDRs and are able to produce $1,25(\mathrm{OH})_{2} \mathrm{D}_{3}$. This implies that the vitamin exerts its action beyond its classic hormonalendocrine function tending towards an autocrine role [6].

\section{Vitamin D and Its Role in Immune Regulation}

Vitamin D affects the immune system acting at various levels, such as antibacterial response, antigen presentation, and regulation of adaptive and innate immunity. Genome-wide analysis has revealed that a large number of genes are influenced by vitamin D levels [7]. VDRs have been discovered in almost all immune cells as activated or naïve $\mathrm{CD} 4^{+}$and $\mathrm{CD}^{+} \mathrm{T}$ cells, B cells, neutrophils, and antigen-presenting 
cells (APCs) such as dendritic cells and macrophages. In particular, vitamin $\mathrm{D}_{3}$ enhances the chemotactic and phagocytic responses of macrophages and production of antimicrobial proteins, such as cathelicidin, inhibits the surface expression of the MHC-II-complex antigen and costimulatory molecules and downregulates the production of many proinflammatory cytokines, such as interleukin- (IL-) 1, IL-6, IL-8, and TNF- $\alpha$ $[4,8]$. An experimental study demonstrated that transferring $\mathrm{CD}^{+}{ }^{+} \mathrm{T}$ cells isolated from the spleen of wild type (WT) and IL-10 KO mice into immunodeficient Rag KO recipients, that is, mice with no mature $\mathrm{B}$ or $\mathrm{T}$ cells, did not induce colitis, whereas transferring $\mathrm{CD}^{+} \mathrm{T}$ cells from VDR $\mathrm{KO}$ mice led to colonic inflammation, and transferring $\mathrm{CD} 8^{+} \mathrm{T}$ cells from IL10/VDR KO mice led to fulminant colitis. These data indicate that expression of VDR is required to prevent replication of quiescent $\mathrm{CD}^{+} \mathrm{T}$ cells and that the lack of VDR induced the formation of more aggressive T cells [9]. Another study evaluated the difference of protein expression in the small intestinal mucosa between WT mice and VDR KO mice identifying a higher expression of proteins involved in cell adhesion, proliferation, and migration and stress response in VDR $\mathrm{KO}$ mice. The authors conclude that vitamin D and VDR play a direct, or indirect role, in balancing these functions [10].

Vitamin D/VDR status regulates development, function, and balance of T-lymphocytes dampening T-helper- (Th-) 1 cell function and cytokine patterns (IL-2 and interferon$\gamma(\mathrm{IFN}-\gamma)$ ) by enhancing the Th- 2 cell response (IL-4, IL-5, and IL-10) [11]; moreover $1,25(\mathrm{OH})_{2} \mathrm{D}_{3}$ promotes a regulatory outcome through the inhibition of Th-17 cells and their related cytokines, and the induction of regulatory $\mathrm{T}$ cells (Treg) that are protective against autoimmunity, stimulating the expression of the cytotoxic T-associated protein 4 (CTLA4) and forkhead box P3 (Foxp-3), together with the induction of IL-10 $[12,13]$. In addition, $1,25(\mathrm{OH})_{2} \mathrm{D}_{3}$ appears to have a chemopreventive role through an antiproliferative action, for example, through VDR-mediated inhibition of the Wnt/betacatenin pathway $[8,14,15]$, inhibiting growth without inducing apoptosis and inducing differentiation in colon cancer cell lines $[16,17]$.

The molecular and genetic link between CD and the vitamin $\mathrm{D} / \mathrm{imm}$ une system axis may be in part explained by the NOD2 gene (Figure 1). The precise etiology of the inflammatory bowel disease $\mathrm{CD}$ is unknown. Like many chronic diseases, there are environmental factors that act on a polygenic background. Variants of the NOD2/CARD15 gene are associated with the development and phenotypic patterns of CD. This gene encodes for a protein of the family of intracellular pattern recognition receptors for bacterial components that play an important role in the innate immune system $[18,19]$. Transcription of the NOD2 gene is stimulated by $1,25(\mathrm{OH})_{2} \mathrm{D}_{3} / \mathrm{VDR}$ and signaling through NOD2 induces expression of DEFB2/HBD2 which stands for the antimicrobial peptide beta-defensin 2, and of CAMP which codifies for cathelicidin [20]. In a study on a VDR KO model, a downregulation of the ATG16L1 gene, together with a reduced expression of lysozyme by Paneth cells was reported [21]. These mice had an increased susceptibility to dextran sulfate sodium (DSS) colitis, whereas in human colon samples of low VDR expression correlate with ATG16L1 and a reduction of Bacteroides species. This finding implies that alterations of the vitamin D status might interfere with autophagy and alter the antimicrobial barrier of the intestinal mucosa and, consequently, the control of the microbiota [22].

\section{VDR Polymorphisms in IBD}

From the above, it appears that variants of VDR interfere with the immune system and, thus, may contribute to susceptibility to inflammatory bowel disease (IBD) $[23,24]$. In fact, VDR polymorphisms have been identified in various diseases, such as cancer [25] or cancer risk [26], asthma [27], and kidney diseases [28]. The best-studied polymorphisms include BsmI (rs1544410), FokI (rs2228570), TaqI (rs731236), and ApaI (rs7975232). However, the results of these still few studies in IBD patients are contradictory (Table 1): for example, no statistical significance compared to controls was found in two studies on IBD patients for BsmI, FokI, TaqI, and ApaI [29, 30] with a borderline significance for heterozygous carriage of the FokI allele [29]. In three Chinese studies on ulcerative colitis (UC) patients $[31,32]$ and on CD patients, no difference [32] or an association of the $\mathrm{Bb}$ genotype of the BsmI variant with UC [31] was reported; whereas no association was found for ApaI, TaqI, and BsmI with CD [33].

In another study on European Caucasian patients, a significantly higher frequency of the TaqI polymorphism (genotype "tt") was reported in CD compared to UC or HC [23]. This finding was replicated in German IBD patients where the " $\mathrm{tt}$ " genotype was significantly more frequent in fistulizing and stenosing CD [24]. Subsequently, always in Caucasians, the finding of a lack of association of ApaI but a more frequent presence of TaqI in male IBD patients was reported [34] and confirmed 3 years later [35].

Concerning BsmI polymorphisms, the BB genotype was more frequent in Ashkenazi UC patients compared to Ashkenazi controls [36]. Finally, in a mixed IBD population investigating all 4 VDR variants, only the Fok I variant ("ff" genotype) was significantly more frequent in IBD patients [37].

Two recent meta-analyses including the same 9 studies with slightly different patient numbers (Table 1) yielded different results $[38,39]$; Xue et al. [38] found that the "ff" genotype of FokI was associated with a significant risk for UC in Asians, whereas the " $\mathrm{tt}$ " genotype of TaqI was associated with an increased risk for $\mathrm{CD}$ in Europeans, but with an increased risk for both diseases, CD and UC, in Asian males. Carriage of the "a" allele (ApaI) resulted protective from CD. In contrast, Wang et al. [39] concluded that there was no association between ApaI, BsmI, and FokI and IBD, whereas subgroup analysis evidenced an increased risk for CD for ApaI and limited to East Asians, for BsmI. Conversely, TaqI variants reduced the risk for UC in Caucasians.

One study examined the influence of VDR polymorphisms on serum vitamin D levels [40] (not included in Table 1) showing a significant association of variants of the TaqI and the signal peptide, CUB domain, and EGF-like 3 (SCUBE3, rs732594) genes, the latter encodes for a protein involved in the VDR pathway, in CD patients, whereas ApaI and SCUBE3 and two variants of PHD finger protein-11 


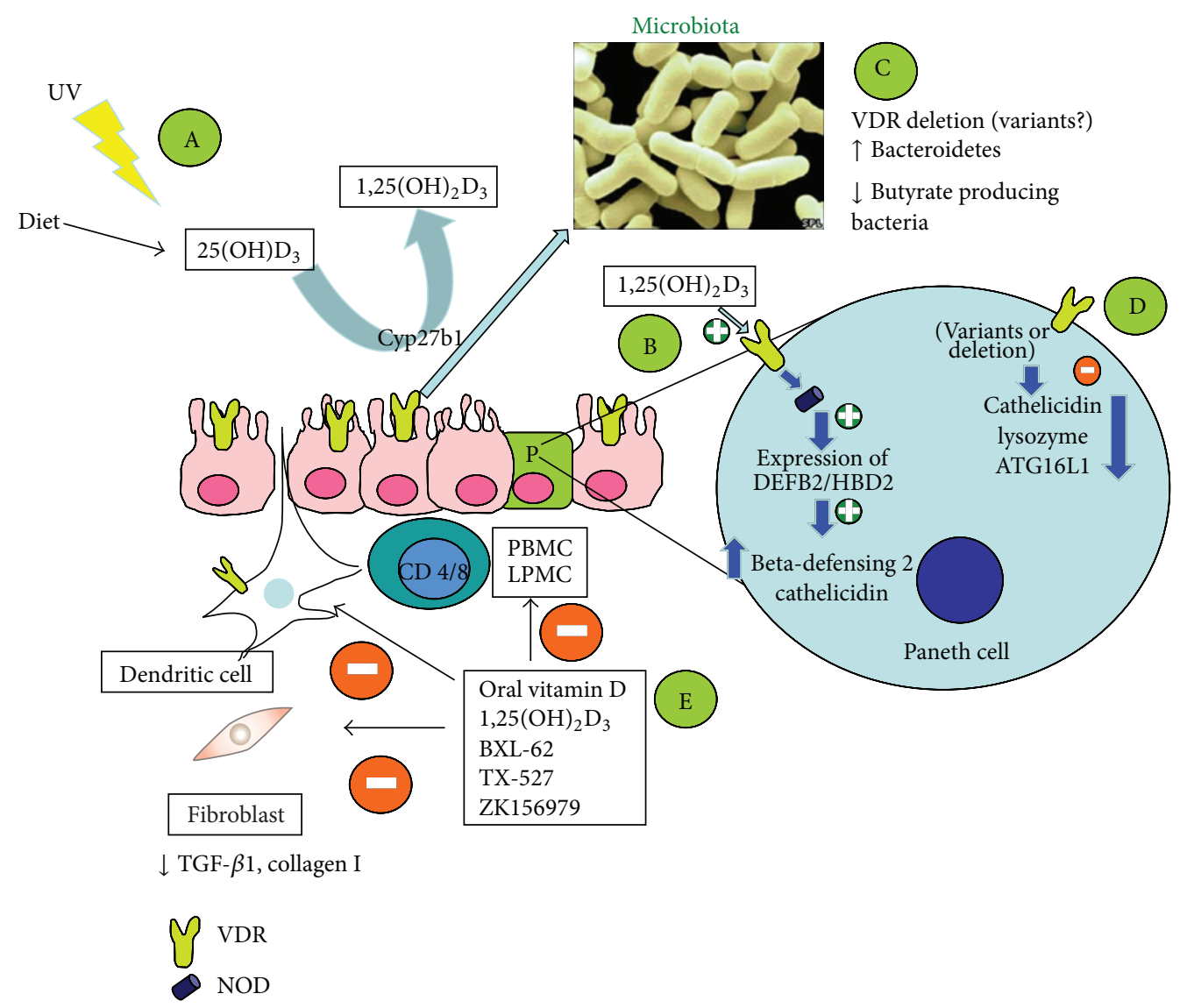

FIGURE 1: Potential involvement of vitamin D in the pathogenesis of inflammatory bowel disease and immunologic effects of vitamin-Drelated therapeutic approaches. Scenario A: reduced UV exposure as risk factor for CD and for hospitalizations and surgery [86]; Scenario B: NOD2 gene transcription is stimulated by $1,25(\mathrm{OH})_{2} \mathrm{D}_{3} / \mathrm{VDR}$ and signaling through NOD2 induces expression of DEFB2/HBD2 which stands for beta-defensin 2 and cathelicidin [20]; Scenarios C and D: variants or loss of function of VDR may lead to changes of the microbiota and reduce host defense by reducing production of cathelicidin, lysozyme, and ATG16L1 protein (autophagy) [21, 22]; Scenario E: experimental studies with vitamin D or its analogues showing inhibitory effects on PBMC, LPMC, dendritic cells, and fibroblasts in terms of cytokine production and differentiation (Table 3). VDR: vitamin D receptor; NOD: nucleotide-binding oligomerization domain.

(PHF-11) gene, namely, rs2980 and rs2981, showed a significant association with serum vitamin D levels in CD patients. PHF-11 variants have been shown to be involved with vitamin D levels in other pathologies, such as asthma [41].

Besides investigations on VDR variants, 2 SNPs of the vitamin D-binding protein (DBP), that is, the 416 variant Glu (rs7041) and the 420 variant Lys (rs4588), were analysed. A significantly reduced frequency of the 420 variant Lys was found in IBD patients compared to controls [42].

In conclusion, the influence of VDR variants on IBD risk is still poorly defined. Interesting approaches are represented by investigations on the association between polymorphisms and vitamin $\mathrm{D}$ levels and those examining proteins involved in vitamin D-related pathways, but all need further studies and confirmation.

\section{Vitamin D Status and Related Risk Factors in IBD}

Starting in the late seventies, investigations on the vitamin D status of IBD patients have been carried out with different methodological approaches and results. By comparing IBD patients (CD alone or mixed populations) versus healthy controls (HC), no differences were found for circulating $25(\mathrm{OH}) \mathrm{D}_{3}$ concentrations in 6 studies on adult IBD populations [43-48] and in 1 study on a pediatric cohort [49], whereas lower plasma levels were reported in undernourished CD patients [50], in CD patients after intestinal resections [51], in 2 studies on adult, and in 1 study on pediatric CD patients [52-54] and in 3 mixed IBD populations [55-57].

Comparing $25(\mathrm{OH}) \mathrm{D}_{3}$ levels between $\mathrm{CD}$ and $\mathrm{UC}$ patients, no differences were found in 8 studies on adult or pediatric patients in basal conditions $[47,54,55,57-61]$ and in 1 pediatric study on partially vitamin $\mathrm{D}$ supplemented patients [62]. Lower levels in CD compared with UC were found in 5 studies [46, 63-66].

Finally, investigations concerning the active form of vitamin $\mathrm{D}, 1,25(\mathrm{OH})_{2} \mathrm{D}_{3}$, reported normal levels after bowel resections in $\mathrm{CD}$ [67] but no differences between well- and undernourished CD patients compared to HC or in wellnourished UC patients [50]. Similar findings were reported in a pediatric study including $\mathrm{CD}, \mathrm{UC}$ and $\mathrm{HC}$ [61]. Lower 
TABLE 1: Genetic polymorphisms and IBD (chronological order).

\begin{tabular}{|c|c|c|c|c|}
\hline Author & Year & Population & $\begin{array}{l}\text { Investigated gene } \\
\text { polymorphisms }\end{array}$ & Main findings \\
\hline \multicolumn{5}{|c|}{ Single- or multicenter studies } \\
\hline Simmons et al. [23] & 2000 & $\begin{array}{l}\text { England } 158 \text { UC, } 245 \text { CD, } \\
164 \text { CRADC }\end{array}$ & VDR: TaqI, ApaI, FokI & $\begin{array}{l}\text { TaqI polymorphism (“tt" genotype) } \\
\text { more frequent in CD compared to UC } \\
\text { or controls }\end{array}$ \\
\hline Martin et al. [24] & 2002 & Germany, 95 CD, 93 UC, 119 HC & VDR: TaqI & $\begin{array}{l}\text { TaqI ("tt" genotype) significantly more } \\
\text { frequent in fistulizing and stenosing CD }\end{array}$ \\
\hline $\begin{array}{l}\text { Dresner-Pollak et al. } \\
\text { [36] }\end{array}$ & 2004 & $\begin{array}{l}\text { Israel, } 228 \text { CD (129 Ashkenazi } \\
\text { and } 99 \text { non-Ashkenazi), } 151 \mathrm{UC} \\
\text { (72 Ashkenazi, } 79 \\
\text { non-Ashkenazi), } 495 \mathrm{HC}(352 \\
\text { non-Ashkenazi and } 143 \\
\text { Ashkenazi) }\end{array}$ & VDR: BsmI & $\begin{array}{l}\text { BB genotype more frequent in } \\
\text { Ashkenazi UC compared to Ashkenazi } \\
\text { HC }\end{array}$ \\
\hline Noble et al. [34] & 2008 & $\begin{array}{l}\text { United Kingdom, } 286 \text { CD, } 154 \\
\text { UC, } 240 \mathrm{HC}\end{array}$ & VDR: TaqI, ApaI & $\begin{array}{l}\text { Overall no differences between CD, UC, } \\
\text { and HC for TaqI and ApaI. TaqI variants } \\
\text { more frequent in male IBD patients } \\
\text { compared to (male) HC }\end{array}$ \\
\hline Naderi et al. [37] & 2008 & Iran, $150 \mathrm{UC}, 80 \mathrm{CD}, 150 \mathrm{HC}$ & $\begin{array}{l}\text { VDR: ApaI, TaqI, BsmI, } \\
\text { FokI }\end{array}$ & $\begin{array}{l}\text { FokI polymorphism significantly higher } \\
\text { in UC and CD. Frequency of } \\
\text { polymorphic "f" allele and f/f genotype } \\
\text { higher in UC and CD comparing with } \\
\text { HC }\end{array}$ \\
\hline Pluskiewicz et al. [30] & 2009 & Poland, $47 \mathrm{UC}, 47 \mathrm{HC}$ & VDR: TaqI, BsmI, ApaI & No differences between UC and HC \\
\hline Hughes et al. [29] & 2011 & Ireland, $660 \mathrm{IBD}, 699 \mathrm{HC}$ & $\begin{array}{l}\text { VDR: ApaI, TaqI, BsmI, } \\
\text { FokI }\end{array}$ & $\begin{array}{l}\text { Borderline significance for heterozygous } \\
\text { carriage of the FokI allele }\end{array}$ \\
\hline Pei et al. [31] & 2011 & China, $218 \mathrm{UC}, 251 \mathrm{HC}$ & $\begin{array}{l}\text { VDR: ApaI, TaqI, BsmI, } \\
\text { FokI }\end{array}$ & $\begin{array}{l}\text { Only Bb genotype of the BsmI variant } \\
\text { associated with UC; frequency of the } \\
\text { BsmI polymorphic allele (B) increased } \\
\text { in UC }\end{array}$ \\
\hline Eloranta et al. [42] & 2011 & $\begin{array}{l}\text { Switzerland, } 404 \mathrm{CD}, 232 \mathrm{UC} \text {, } \\
248 \mathrm{HC}\end{array}$ & DBP: rs 7041, rs 4588 & $\begin{array}{l}\text { Significantly reduced frequency of the } \\
420 \text { variant Lys in IBD compared to } \\
\text { controls }\end{array}$ \\
\hline Bentley et al. [35] & 2011 & $\begin{array}{l}\text { New Zealand, } 449 \text { CD, } 448 \text { UC, } \\
482 \text { HC }\end{array}$ & VDR: FokI, TaqI & $\begin{array}{l}\text { No overall differences, only a higher } \\
\text { minor allele frequency for TaqI, in male } \\
\text { CD and UC compared to HC }\end{array}$ \\
\hline Luo et al. $[33]^{*}$ & 2013 & China, 19 CD, $122 \mathrm{HC}$ & VDR: ApaI, TaqI, BsmI & $\begin{array}{l}\text { No significant differences in the } \\
\text { frequencies of TaqI, BsmI, and ApaI } \\
\text { polymorphisms }\end{array}$ \\
\hline Xia et al. [32] & 2014 & China 382 UC, 489 HC & $\begin{array}{l}\text { VDR: ApaI, TaqI, BsmI, } \\
\text { FokI }\end{array}$ & $\begin{array}{l}\text { No difference between UC and HC. The } \\
\text { mutant allele C and genotype TC + CC } \\
\text { of FokI were significantly increased in } \\
\text { patients with mild and moderate UC } \\
\text { compared to severe UC. The frequency } \\
\text { of AAC haplotype was statistically lower } \\
\text { in UC than HC (AAC haplotype formed } \\
\text { by the VDR BsmI, ApaI, and TaqI gene } \\
\text { might engender a reduced risk of UC } \\
\text { attack) }\end{array}$ \\
\hline \multicolumn{5}{|c|}{ Meta-analyses } \\
\hline Xue et al. [38] & 2013 & $\begin{array}{l}\text { ApaI: } 1024 \text { CD, } 974 \text { UC, } 1551 \mathrm{HC} \\
\text { FokI: } 1187 \mathrm{CD}, 1221 \mathrm{UC}, 1746 \mathrm{HC} \\
\text { BsmI: } 721 \mathrm{CD}, 813 \mathrm{UC}, 1642 \mathrm{HC} \\
\text { TaqI: } 1568 \mathrm{CD}, 1515 \mathrm{UC}, 2152 \mathrm{HC}\end{array}$ & $\begin{array}{l}\text { VDR: ApaI, TaqI, BsmI, } \\
\text { FokI }\end{array}$ & $\begin{array}{l}\text { FokI "ff" genotype associated with a } \\
\text { significant risk for UC in Asians; TaqI } \\
\text { "tt" genotype associated with an } \\
\text { increased risk for CD in Europeans and } \\
\text { with an increased risk for CD and UC in } \\
\text { Asian males. ApaI "a" allele confers } \\
\text { protection from CD }\end{array}$ \\
\hline
\end{tabular}


TABle 1: Continued.

\begin{tabular}{|c|c|c|c|c|}
\hline Author & Year & Population & $\begin{array}{l}\text { Investigated gene } \\
\text { polymorphisms }\end{array}$ & Main findings \\
\hline Wang et al. [39] & 2014 & $\begin{array}{l}\text { ApaI: } 940 \mathrm{CD}, 962 \mathrm{UC}, 1468 \mathrm{HC} \\
\text { FokI: } 1098 \mathrm{CD}, 1217 \mathrm{UC}, 1676 \mathrm{HC} \\
\text { BsmI: } 713 \mathrm{CD}, 799 \mathrm{UC}, 1616 \mathrm{HC} \\
\text { TaqI: } 1553 \mathrm{CD}, 1500 \mathrm{UC}, 2145 \mathrm{HC}\end{array}$ & $\begin{array}{l}\text { VDR: ApaI, TaqI, BsmI, } \\
\text { FokI }\end{array}$ & $\begin{array}{l}\text { ApaI, BsmI, and FokI are not } \\
\text { significantly associated with IBD. } \\
\text { Significant association between TaqI } \\
\text { polymorphism and IBD risk. } \\
\text { In subgroups, ApaI increases the overall } \\
\text { CD risk and BsmI increases this CD risk } \\
\text { only in East Asians, whereas TaqI } \\
\text { reduces the risk for UC especially in } \\
\text { Caucasians }\end{array}$ \\
\hline
\end{tabular}

CD: Crohn's disease; UC: ulcerative colitis; CRADC: cadaveric renal allograft donor controls; PCR: polymerase chain reaction; IBD: inflammatory bowel disease; HC: healthy controls; DBP: vitamin-D-binding protein; VDR: vitamin D receptor.

${ }^{*}$ Article in Chinese.

$1,25(\mathrm{OH})_{2} \mathrm{D}_{3}$ concentrations compared to controls were found in 2 studies including $\mathrm{CD}$ and UC patients $[45,68]$ Conversely, elevated levels of $1,25(\mathrm{OH})_{2} \mathrm{D}_{3}$ were reported after ileal resections in $\mathrm{CD}$ [51]. In this latter study, a positive correlation with $25(\mathrm{OH}) \mathrm{D}_{3}$ levels and PTH was reported.

Changing methodology and introducing vitamin $\mathrm{D}$ reference values as parameter, the importance of vitamin $D$ in IBD has become more convincing. Defining vitamin sufficiency as serum values above $30 \mathrm{ng} / \mathrm{mL}$, vitamin D insufficiency as values between $10 / 20$ and $30 \mathrm{ng} / \mathrm{mL}$, and vitamin deficiency as concentrations below 10 to $15 \mathrm{ng} / \mathrm{mL}$, data from 27 studies from all over the world were available $[44,46,52,53,56-$ $58,60,61,63,64,69-77], 6$ of them on cohorts over 100 participants [59, 62, 66, 78-80], and one with more than 1,000 patients [81]. In synthesis, vitamin deficiency was found in $8-100 \%$ of patients with $\mathrm{CD}$ and in $15-60 \%$ of patients with UC, vitamin insufficiency in $12-72.3 \%$ in $\mathrm{CD}$ or in mixed IBD populations and in 7-64\% of UC patients. Five papers $[53,61,74,76,82]$ differentiated vitamin $\mathrm{D}$ levels according to seasonal variations in $\mathrm{CD}$ patients reporting vitamin deficiency in $50-76 \%$ in winter and in $10-19 \%$ in summer months; vitamin insufficiency, where reported [76, 82 ], was indicated in $73-100 \%$ in winter and $55-59 \%$ in summer months.

Studies evaluating vitamin D levels in IBD patients were all conducted after disease onset and established diagnosis, but it is not clear if vitamin D deficiency is the cause or a consequence. Pathogenesis of vitamin D hypovitaminosis in patients with IBD may depend on various mechanisms such as decreased exposure to sunlight or oral vitamin D intake, ileal resections leading to malabsorption or a disturbed enterohepatic circulation, and/or increased losses through the gastrointestinal system by protein-losing enteropathy [59].

To identify the reasons for the differences of the vitamin $\mathrm{D}$ status, the ability to absorb vitamin $\mathrm{D}_{2}$ was evaluated in a study by Farraye et al. [77] comparing CD patients and HC. In this study, $42 \%$ of $\mathrm{CD}$ patients were vitamin $\mathrm{D}$ deficient $25(\mathrm{OH}) \mathrm{D}_{3}(\leq 20 \mathrm{ng} / \mathrm{mL})$, while $29 \%$ were insufficient $\left(25(\mathrm{OH}) \mathrm{D}_{3}: 21-29 \mathrm{ng} / \mathrm{mL}\right) ; 12 \mathrm{~h}$ after ingesting $50,000 \mathrm{IU}$ of vitamin $\mathrm{D}_{2}$, circulating levels of this metabolite were significantly lower in $\mathrm{CD}$ compared with $\mathrm{HC}$ indicating a significant $30 \%$ reduction of the ability to absorb vitamin $\mathrm{D}_{2}$. In another study, on $31 \mathrm{CD}$ patients and $15 \mathrm{HC}$, the capacity of absorbing orally administered vitamin D $(5 \mu \mathrm{g}$ of $25(\mathrm{OH}) \mathrm{D}_{3} / \mathrm{kg}$ body weight) was evaluated; $10 \%$ of $\mathrm{CD}$ patients showed decreased absorption of $25(\mathrm{OH}) \mathrm{D}_{3}$ after 4 and 8 hours [71]. Finally, a wide variability of absorption of vitamin $\mathrm{D}_{2}$ was reported in vitamin deficient and insufficient CD patients, but vitamin $\mathrm{D}_{2}$ absorption was significantly reduced compared with $\mathrm{HC}$ [77].

Several studies evaluated factors influencing vitamin D status hypothesizing reduced sun exposure as cause for hypovitaminosis, since a geographical north-south gradient was noted also for other autoimmune $\mathrm{T}$ helper- (Th-) 1mediated diseases, like multiple sclerosis. The link between this gradient and the pathophysiological mechanisms that involve vitamin D status depends not only on dietary intake but also from UV exposure [83]. Indeed, a negative association between sun exposure and lower levels of $25(\mathrm{OH}) \mathrm{D}$ in $\mathrm{CD}$ was reported in Indian patients [52] and, most recently, also in Dutch CD [84] where reduced exposure to sunlight (defined as no sunny holidays, no solarium use, and more sun protection) was associated with low $25(\mathrm{OH}) \mathrm{D}$ serum levels.

The relationship between sun exposure and the risk of developing CD or UC has been investigated by Nerich et al. [85]. High residential sunlight exposure was associated with a significant decreased risk of CD, but not UC. Four years later, the same group published similar results, that is, an increased incidence of $C D$ with reduced sunlight exposure, in a cohort of women living in France, whereas vitamin D intake was not associated with a risk reduction in CD or UC [86].

Reduced UV exposure seems therefore not only to increase risk for $\mathrm{CD}$, but it also seems associated with a worse outcome of disease. In a recent nationwide North-American study, the influence of UV exposure on hospitalization rates, length of hospital stay, and surgeries was investigated in an impressive number of IBD patients $(649,932 \mathrm{CD}, 384,267 \mathrm{UC}$, and 288,894,297 non-IBD controls). Reduced UV exposure led to significantly longer hospitalizations in all groups and to more frequent intestinal surgeries and deaths in CD [87]. Data on $25(\mathrm{OH}) \mathrm{D}_{3}$ were not available in this study. The finding that more UV exposure is associated with a minor number of surgical procedures in $\mathrm{CD}$ was confirmed in 
a subsequent study on 481,712 CD-related hospitalizations reporting 67,751 major surgical procedures [88].

Finally, a prospective cohort study of 72,179 women enrolled in the Nurses' Health Study addressed the question if vitamin $\mathrm{D}$ hypovitaminosis may, per se, represent a risk factor for the development of IBD. Incident cases of CD and UC were recorded over a follow-up period of 22 years. A $25(\mathrm{OH}) \mathrm{D}_{3}$ prediction score based on diet and lifestyle was developed and validated against effectively measured levels of $25(\mathrm{OH}) \mathrm{D}_{3}$. The authors showed that higher predicted plasma levels of $25(\mathrm{OH}) \mathrm{D}_{3}$ were associated with a significant risk reduction for $\mathrm{CD}$ but not for $\mathrm{UC}$, suggesting that vitamin $\mathrm{D}$ status may contribute to the pathogenesis of CD [89].

After a series of contradictory and mostly negative studies on vitamin D levels in IBD patients compared with $\mathrm{HC}$, more conclusive data have been produced introducing reference values. However, most of these studies have been aimed to investigate bone and calcium metabolism. Recent large cohort studies investigating UV exposure or vitamin D status estimating the risk to develop IBD have pushed forward our understanding on the potential role of vitamin $\mathrm{D}$ in the context of IBD.

\section{Vitamin D Status and Clinical Outcome in IBD Patients}

Several studies concerning the relationship between vitamin $\mathrm{D}$ status and clinical outcome in IBD patients have been published (Table 2). Almost 30 years ago, $25(\mathrm{OH}) \mathrm{D}_{3}$ levels in active $\mathrm{CD}$ were found to be lower than in quiescent CD [50]. Twenty years later, another study showed that low serum $25(\mathrm{OH}) \mathrm{D}_{3}$ levels were predicted by disease duration and activity scores in both, CD and UC [46]. This inverse association between disease activity and serum $25(\mathrm{OH}) \mathrm{D}_{3}$ levels was confirmed in a small prospective study in CD [52] and in a retrospective study on a much larger, mixed IBD population [59]. In this latter study, low serum $25(\mathrm{OH}) \mathrm{D}_{3}$ levels were associated with higher clinical activity scores in $\mathrm{CD}$ and in UC, but not with the risk for medical or surgical hospitalizations. Moreover, regression analysis found that low vitamin D levels were independently associated with quality of life (QoL) in CD patients but not in UC patients. A reduced QoL was reproduced by another study where vitamin insufficient patients had significantly lower QoL scores than those who were sufficient [82]. Finally, in a mixed IBD population, an inverse correlation between serum $25(\mathrm{OH}) \mathrm{D}_{3}$ concentrations and fecal calprotectin, a marker for gut inflammation, was found whereas serum CRP as a marker of systemic inflammation did not correlate with $25(\mathrm{OH}) \mathrm{D}_{3}$ levels [90].

Conversely, other studies on CD and UC patients failed to show a correlation between serum $25(\mathrm{OH}) \mathrm{D}_{3}$ levels and disease activity [60]. The same findings, that is, no association between $25(\mathrm{OH}) \mathrm{D}_{3}$ concentrations and disease activity, were published on a pediatric IBD population [54].

Going beyond disease activity, in a prospective study on the largest multicenter cohort involving 3,217 patients, low plasma $25(\mathrm{OH}) \mathrm{D}_{3}$ levels $(<20 \mathrm{ng} / \mathrm{mL})$ were associated with an increased risk of hospitalizations and surgery for $\mathrm{CD}$ as well as for UC patients [81]. In a subset of CD patients, but not UC patients, who normalized vitamin $\mathrm{D}$ status, a reduction of CRP levels and the need for hospitalizations was observed.

The likelihood for developing Clostridium difficile $(\mathrm{Cl})$ colitis related to vitamin D status was investigated retrospectively. There was an increased risk for developing $\mathrm{Cl}$ colitis in patients with low plasma $25(\mathrm{OH}) \mathrm{D}_{3}$ levels $(<20 \mathrm{ng} / \mathrm{mL})$, and an increase by $1 \mathrm{ng} / \mathrm{mL}$ of $25(\mathrm{OH}) \mathrm{D}_{3}$ was accompanied by a $4 \%$ risk reduction of developing $\mathrm{Cl}$ colitis. Lastly, death from $\mathrm{Cl}$ colitis occurred in those with lower $25(\mathrm{OH}) \mathrm{D}_{3}$ levels compared with survivors [91]. A recent study investigated the relationship between $25(\mathrm{OH}) \mathrm{D}_{3}$ concentrations and duration of anti-TNF therapy in IBD patients. Interestingly, low vitamin $\mathrm{D}$ levels were associated with loss of response during maintenance therapy in CD patients [92], whereas serum $25(\mathrm{OH}) \mathrm{D}_{3}$ levels increased with anti-TNF therapy [93].

The only study that investigated plasma $1,25(\mathrm{OH})_{2} \mathrm{D}_{3}$ levels found no association between $1,25(\mathrm{OH})_{2} \mathrm{D}_{3}$ levels and CDAI or CAI in Japanese patients [68].

From the above, it appears that low vitamin D is inversely correlated to disease activity documented by clinical scores and surrogate markers of inflammation such as CRP and fecal calprotectin; moreover, low levels were also associated with clinical outcomes, that is, surgery, response to antiTNF therapy, $\mathrm{Cl}$ superinfection, and, finally, death. Inflammation per se has been shown to upregulate conversion from $25(\mathrm{OH}) \mathrm{D}_{3}$ to $1,25(\mathrm{OH})_{2} \mathrm{D}_{3}$ which may lead to a reduction of available $25(\mathrm{OH}) \mathrm{D}_{3}$. In this discussion, an observation of two recent papers may be relevant, coming from orthopaedic surgery, showing an acute reduction of $25(\mathrm{OH}) \mathrm{D}_{3}$ levels following a systemic inflammatory response induced by surgery, considering serum $25(\mathrm{OH}) \mathrm{D}_{3}$ as a negative acute phase reactant $[94,95]$.

\section{Therapeutic Studies In Vitro and in Experimental Animals}

As a result of this evidence, vitamin $\mathrm{D}$ should be proposed as a therapy for IBD. Several experimental studies, both on animals and IBD patients, have been carried out (Table 3). Starting with the former, in a model of spontaneous colitis, interleukin- (IL-) 10 knock-out (KO) mice on a vitamin $\mathrm{D}$ deficient diet showed growth retardation and weight loss, together with a high mortality rate $(58 \%$ at week 9) compared to mice on a vitamin $\mathrm{D}$ sufficient diet; $1,25(\mathrm{OH})_{2} \mathrm{D}_{3}(0.005 \mu \mathrm{g} /$ day $)$ supplementation starting from week 2 reduced weight loss and ameliorated histology scores, but vitamin $\mathrm{D}$ supplementation after symptom onset at week $7\left(1,25(\mathrm{OH})_{2} \mathrm{D}_{3}, 0.2 \mu \mathrm{g} /\right.$ day $)$ did not induce significant differences compared with untreated animals, except for bowel weight indicating a reduction of inflammation in supplemented animals [96]. In another study, the efficacy of a low calcemic vitamin D analogue (22-ene-25-oxa-vitamin $\mathrm{D}$ (ZK156979)) was investigated in 2,4,6-trinitrobenzene sulfonic acid (TNBS) colitis [97]. Treatment was performed with $1,25(\mathrm{OH})_{2} \mathrm{D}_{3}(0.2 \mu \mathrm{g} / \mathrm{kg})$ versus $\mathrm{ZK} 156979(0.1-2.0 \mu \mathrm{g} / \mathrm{kg})$, both administered intraperitoneally (i.p.) before or after colitis induction. Assessment of inflammation and colitis severity 
TABLE 2: Vitamin D versus disease activity and outcome in IBD (chronological order).

\begin{tabular}{|c|c|c|c|}
\hline Author & Year & Population & Methodology \\
\hline Harries et al. [50] & 1985 & $\begin{array}{l}\text { U.S.A } \\
40 \mathrm{CD} \\
20 \mathrm{UC} \\
9 \mathrm{HC} \\
\end{array}$ & $\begin{array}{l}\text { Single-center cohort; CD divided into } 2 \\
\text { groups (undernourished and well } \\
\text { nourished); } 2 \text { control groups: } 20 \\
\text { well-nourished UC and } 9 \text { HC }\end{array}$ \\
\hline Tajika et al. [46] & 2004 & $\begin{array}{l}\text { Japan } \\
33 \mathrm{CD} \\
11 \mathrm{UC} \\
15 \mathrm{HC}\end{array}$ & $\begin{array}{l}\text { Single-center cohort; } 25(\mathrm{OH}) \mathrm{D}_{3} \text { and } \\
\text { disease activity assessed by CDAI and } \\
\text { IOIBD score }\end{array}$ \\
\hline
\end{tabular}

\begin{tabular}{|c|c|c|c|}
\hline Joseph et al. [52] & 2009 & $\begin{array}{l}\text { India } \\
34 \mathrm{CD} \\
34 \mathrm{HC}\end{array}$ & $\begin{array}{l}\text { Single-center cohort; disease activity } \\
\text { evaluated by } \mathrm{HBI} \text { in } \mathrm{CD}\end{array}$ \\
\hline
\end{tabular}
Main findings

$25(\mathrm{OH}) \mathrm{D}_{3}$ significantly lower in $\mathrm{CD}$ with active disease versus inactive disease $(P<$ $0.05)$

Serum $25(\mathrm{OH}) \mathrm{D}_{3}$ significantly related to disease duration $(r=0.46, P=0.003)$, CDAI $(r=0.44, P=0.005)$, IOIBD score $(r=0.30, P<0.05)$, serum ferritin $(r=$ $0.34, P=0.03), \operatorname{CRP}(r=0.34, P=0.03)$

Serum $25(\mathrm{OH}) \mathrm{D}_{3}$ in $\mathrm{CD}$ significantly lower versus controls $(P<0.05)$. Disease activity correlated negatively with $25(\mathrm{OH}) \mathrm{D}_{3}$ level $(P<0.004) .25(\mathrm{OH}) \mathrm{D}_{3}$ levels were comparable to controls in mild CD but were significantly lower in moderate and severe CD

$\begin{array}{ccc}\text { Nakajima et al. [68] } 2011 \quad \text { Japan } & \begin{array}{l}\text { Single-center cohort; disease activity } \\ \text { measured using CAI/CDAI scores }\end{array}\end{array}$

\begin{tabular}{lcl}
\hline & U.S.A. & $\begin{array}{l}\text { Single-center cohort; retrospective } \\
\text { observational study }\end{array}$ \\
Ulitsky et al. [59] $2011 \quad 504$ IBD (403 CD, 101 & $\begin{array}{l}\text { HRQOL measured with SIBDQ, disease } \\
\text { activity measured using HBI/UCDI } \\
\text { scores }\end{array}$ \\
& UC) &
\end{tabular}

Cross-sectional pediatric study. Disease activity measured by PCDAI e PUCAI

\begin{tabular}{lccc} 
El-Matary et al. & \multicolumn{2}{c}{ Canada } & Cross-sectional pediatric study. Disease \\
[54] & 6011 & IBD (39 CD, 21 & activity measured by PCDAI e PUCAI
\end{tabular}

No decrease $1,25(\mathrm{OH})_{2} \mathrm{D}_{3}$ in $\mathrm{CD}$ with high CDAI

No significant correlation between serum $1,25(\mathrm{OH})_{2} \mathrm{D}_{3}$ levels and CAI or CDAI in $\mathrm{UC}$ or $\mathrm{CD}$

$25(\mathrm{OH}) \mathrm{D}_{3}$ deficiency significantly associated with lower SIBDQ $(P=0.002)$ and higher mean HBI/UCDI $(P=0.002)$ in IBD versus vit $D$ sufficient patients. Analyzed separately, vit D deficiency associated with lower HRQOL scores only in $\mathrm{CD}(P=0.04)$, not in UC

No correlation between PCDAI and serum $25(\mathrm{OH}) \mathrm{D}_{3}$. Marginal evidence against the null hypothesis $(P=0.05)$ between serum $25(\mathrm{OH}) \mathrm{D}_{3}$ and PUCAI, but without statistical significance

Serum vit $\mathrm{D}$ lower in active versus inactive disease (non significantly). VitD deficiency was not associated with IBD activity (also considering CD and UC separately), however was associated with a history of IBD related intestinal surgery

IBD-related surgery: CD: $10 \%$ patients never vitamin D deficient versus $13 \%$ vitamin D insufficient versus $17 \%$ vitamin D deficient. UC: vitamin D deficiency associated with elevated risk of surgery and hospitalization with effect similar to CD; no statistical significance in patients vitamin $\mathrm{D}$ insufficient.

Normalization of $25(\mathrm{OH}) \mathrm{D}_{3}$ associated with reduction in the risk of related surgery but not in UC

Patients with insufficient vitamin D demonstrated earlier cessation of anti-TNF- $\alpha$ therapy $(P=0.04)$. This effect was significant in patients who stopped treatment for loss of response, stronger for CD than UC ( $P=\mathrm{NS})$ 
TABLE 2: Continued.

\begin{tabular}{|c|c|c|c|c|}
\hline Author & Year & Population & Methodology & Main findings \\
\hline $\begin{array}{l}\text { Ananthakrishnan } \\
\text { et al. [91] }\end{array}$ & 2014 & $\begin{array}{c}\text { U.S.A. } \\
\text { 3188 IBD patients } \\
(45 \% \text { UC, } 55 \% \text { CD })\end{array}$ & $\begin{array}{l}\text { Retrospective multi-center analysis of } \\
25(\mathrm{OH}) \mathrm{D}_{3} \text { in } 35 \text { patients who developed } \\
\text { CDI }\end{array}$ & $\begin{array}{l}25(\mathrm{OH}) \mathrm{D}_{3} \text { level was significantly lower in } \\
\text { IBD who developed CDI compared to } \\
\text { non-CDI-IBD }(P=0.002) \text {. Levels below } \\
20 \mathrm{ng} / \mathrm{mL} \text { were associated with a two-fold } \\
\text { increase in risk of CDI. } \\
25(\mathrm{OH}) \mathrm{D}_{3} \text { level was an independent } \\
\text { predictor of CDI }\end{array}$ \\
\hline Ham et al. [93] & 2014 & $\begin{array}{l}\text { U.S.A. } \\
37 \text { CD }\end{array}$ & $\begin{array}{l}\text { Prospectively collected samples for } \\
25(\mathrm{OH}) \mathrm{D}_{3} \text { analysis; assessment of } \mathrm{HBI} \\
\text { and CRP } \\
\text { PBMC tested for VDR, Cyp }\end{array}$ & $\begin{array}{l}25(\mathrm{OH}) \mathrm{D}_{3} \text { levels lower in patients with } \\
\text { active disease versus inactive disease, } \\
25(\mathrm{OH}) \mathrm{D}_{3} \text { correlated with HBI (not with } \\
\mathrm{CRP}) \\
\text { PBMC: mean gene expression of VDR } \\
\text { and CypB1 higher in active disease }\end{array}$ \\
\hline Garg et al. [90] & 2013 & $\begin{array}{l}\text { Australia } \\
40 \mathrm{CD} \\
31 \mathrm{UC} \\
23 \mathrm{HC}\end{array}$ & $\begin{array}{l}\text { Assessment of } 25(\mathrm{OH}) \mathrm{D}_{3} \text {, fecal } \\
\text { calprotectin and CRP }\end{array}$ & $\begin{array}{l}\text { Inverse correlation between serum } \\
25(\mathrm{OH}) \mathrm{D}_{3} \text { and fecal calprotectin in } \mathrm{CD} \\
\text { and UC patients, but not with CRP }\end{array}$ \\
\hline Hlavaty et al. [82] & 2014 & $\begin{array}{l}\text { Slovakia } \\
141 \mathrm{CD} \\
49 \mathrm{UC}\end{array}$ & $\begin{array}{l}\text { SIBDQ assessment in vitamin D sufficient } \\
\text { or -deficient patients and in vitamin } \\
\text { supplement ( } 800 \mathrm{IU} / \text { day for } 3 \text { months) } \\
\text { patients }\end{array}$ & $\begin{array}{l}\text { SIBDQ was significantly better in vitamin } \\
\text { D-sufficient patients; } \\
\text { vitamin D supplements did not influence } \\
\text { vitamin D status or sIBDQ }\end{array}$ \\
\hline Govani et al. [88] & 2015 & $\begin{array}{l}\text { U.S.A. } \\
67,751 \mathrm{CD}\end{array}$ & $\begin{array}{l}\text { Retrospective, national, analysis of UV } \\
\text { exposure and inpatient surgery risk }\end{array}$ & $\begin{array}{l}\text { UV exposure protective for inpatients } \\
\text { surgery }\end{array}$ \\
\hline
\end{tabular}

Abbreviations: CD: Crohn's disease; UC: ulcerative colitis; HC: healthy controls; IBS: irritable bowel syndrome; IBD: inflammatory bowel disease; CDAI: Crohn's Disease Activity Index; IOIBD: international organization for the study of inflammatory bowel disease score; CAI: Lichtiger's clinical activity index; $25(\mathrm{OH}) \mathrm{D}_{3}$ : 25-Hydroxycholecalciferol; 1,25(OH $)_{2} \mathrm{D}_{3}$ : 1,25dihydroxycholecalciferol; SIBDQ: Short IBD Questionnaire; HBI: Harvey-Bradshaw index; UCDI: Ulcerative colitis disease activity index; HRQOL: health-related quality of life; PCDAI: pediatric Crohn's disease activity index; PUCAI: pediatric ulcerative colitis activity index; CDI: Clostridium difficile infection; CRP: C-reactive protein; UV: ultraviolet; TNF: tumor necrosis factor; PBMC: peripheral blood mononuclear cells; Cyp: Cyp27b1 gene; VDR: vitamin D receptor.

was established by scoring colitis, macroscopic and histological analysis, and measurement of myeloperoxidase activity (MPO) and cytokine levels. The authors found that ZK156978 reduced the severity of TNBS-induced colitis with a potency comparable with that of $1,25(\mathrm{OH})_{2} \mathrm{D}_{3}$, downregulating MPO activity, tumor necrosis factor- $\alpha$ (TNF- $\alpha$ ) and interferon- $\gamma$ (IFN- $\gamma$ ) tissue levels, and T-box transcription factor (T-bet) expression, together with an increase of interleukin IL-10 and IL-4 tissue concentrations, without calcemic effects.

Laverny et al. [98] studied the effect of an intrarectally administered vitamin $\mathrm{D}$ receptor agonist $\left(1 \alpha, 25(\mathrm{OH})_{2}-16\right.$ ene-20-cyclopropyl-vitamin $\mathrm{D}_{3}$; BXL-62) in $\mathrm{C} 57 \mathrm{Bl} / 6$ mice with dextran-sodium sulfate- (DSS-) induced (3\%) colitis. BXL-62 treatment $(1 \mu \mathrm{g} / \mathrm{kg})$ compared to $1,25(\mathrm{OH})_{2} \mathrm{D}_{3}$ $(0.3 \mu \mathrm{g} / \mathrm{kg})$ was superior in preventing weight loss and visible fecal blood, together with better stool consistency and histology scores without inducing hypercalcemia. Another synthetic vitamin D agonist, $1 \alpha, 25(\mathrm{OH}) 2-19$-nor-14,20-bisepi23-yne-vitamin $\mathrm{D}_{3}$ (TX527), has been shown to attenuate inflammation in the DSS model of colitis by downregulating IL-1, IL-6, IFN- $\gamma$, and TNF- $\alpha$ as well as the gastrointestinal glutathione peroxidase 2 [99].

There are three very interesting studies which associate vitamin $\mathrm{D}$ or its receptor with intestinal microbiota. First, in Cyp27b1-KO mice, that is, mice unable to produce $1,25(\mathrm{OH})_{2} \mathrm{D}_{3}$, an increased susceptibility to DSS colitis was observed [100]. Oral vitamin supplementation reduced weight loss, whereas treatment with antibiotics greatly attenuated colitis. In these mice, a reduced expression of Ecadherin on epithelial and immune cells was observed pointing towards a more "leaky" gut. Moreover, a reduced number of tolerogenic dendritic cells were observed in the gut of Cyp27b1-KO mice. In these mice, as well as in VDRKO mice, dysbiosis of the microbiota was observed with an increase of the Helicobacteraceae family and a reduction of the Firmicutes and Deferribacteres phyla. The authors concluded that vitamin $\mathrm{D}$ (production or its receptor) is involved in the regulation of the gut microbiota. Second, DSSinduced colitis was reduced together with a lower penetration of adherent-invasive E. coli (AIEC) in mice on a vitaminsufficient diet compared to those fed a vitamin D deficient diet. Moreover, vitamin D hypovitaminosis and DSS colitis led to an increase of Bacteroidetes. In the same paper in Caco cells incubated with or without vitamin $\mathrm{D}$ and then challenged with AIEC, vitamin D maintained transepithelial resistance and prevented tight junctional protein redistribution [101]. The third paper, that reported changes of the microbiota related to interference in the vitamin D system, assessed susceptibility to DSS colitis in conditional VDR KO mice (deletion restricted to the intestinal epithelial cells), along with Paneth cell quantity and quality by means of quantification of lysozyme and ATG16L1 protein expression. 
TABLE 3: Therapeutic studies in experimental and human IBD (chronological order).

\begin{tabular}{|c|c|c|c|c|c|}
\hline Author & Year & Species/cells & Investigational agent & Methodology & Main findings \\
\hline \multicolumn{6}{|c|}{ Animal and in vitro studies } \\
\hline $\begin{array}{l}\text { Cantorna et } \\
\text { al. [96] }\end{array}$ & 2000 & IL-10 KO mice & 1,25(OH $)_{2} \mathrm{D}_{3}$ p.o. & $\begin{array}{l}\text { Exp. 1. Vit. D-deficient IL-10 KO } \\
\text { mice versus vit. D-sufficient mice } \\
\text { (treated with cholecalciferol); } \\
\text { Exp. } 2 \text {. Vit. D-deficient IL10 KO } \\
\text { mice versus } 1,25(\mathrm{OH})_{2} \mathrm{D}_{3^{-}} \\
\text {treated; } \\
\text { Exp. 3. Vit. D treatment after } \\
\text { onset of GI symptoms }\end{array}$ & $\begin{array}{l}\text { Vitamin D sufficiency prevents } \\
\text { enterocolitis in IL-10 KO mice up to } \\
13 \text { weeks; } 1,25(\mathrm{OH})_{2} \mathrm{D}_{3} \text { treatment } \\
\text { ameliorates inflammation }\end{array}$ \\
\hline $\begin{array}{l}\text { Daniel et al. } \\
\text { [97] }\end{array}$ & 2006 & $\mathrm{BALB} / \mathrm{c}$ mice & $\begin{array}{l}\text { TNBS colitis; 22-ene- } \\
\text { 25-oxa-vitamin D } \\
\text { (ZK156979) i.p. } \\
\text { (vitamin D analogue) }\end{array}$ & $\begin{array}{l}\text { Treatment with ZK156979 versus } \\
1,25(\mathrm{OH})_{2} \mathrm{D}_{3} \text { before or after } \\
\text { induction of colitis with TNBS; } \\
\text { investigation of tissue MPO, } \\
\text { TNF- } \alpha \text {, IFN- } \gamma \text {, T-bet, IL-10, and } \\
\text { IL- } 4\end{array}$ & $\begin{array}{l}\text { ZK156979 versus } 1,25(\mathrm{OH})_{2} \mathrm{D}_{3} \\
\text { prevents or ameliorates TNBS colitis } \\
\text { decreasing pro-inflammatory and } \\
\text { increasing anti-inflammatory } \\
\text { cytokines }\end{array}$ \\
\hline $\begin{array}{l}\text { Laverny et al. } \\
\text { [98] }\end{array}$ & 2010 & C57BL/6 mice & $\begin{array}{l}\text { DSS-colitis, } \\
1 \alpha, 25(\mathrm{OH})_{2}-16 \text {-ene- } \\
20 \text {-cyclopropyl- } \\
\text { vitamin D3 (BXL-62) } \\
\text { (=VDR agonist) } \\
\text { intrarectally }\end{array}$ & $\begin{array}{l}\text { Daily administration of BXL- } 62 \\
\text { versus } 1,25(\mathrm{OH})_{2} \mathrm{D}_{3} \text {; } \\
\text { Macro- and microscopic scoring; } \\
\text { mucosal concentrations of } \\
\text { TNF- } \alpha \text {, IL- } 12 / 23 p 40 \text {, IL- } 6 \text {, and } \\
\text { IFN- } \gamma \text { and assessment of mRNA }\end{array}$ & $\begin{array}{l}\text { Higher potency of BXL- } 62 \text { versus } \\
1,25(\mathrm{OH})_{2} \mathrm{D}_{3} \text { in reducing tissue } \\
\text { inflammation }\end{array}$ \\
\hline $\begin{array}{l}\text { Verlinden et } \\
\text { al. [99] }\end{array}$ & 2013 & C57BL/6 mice & $\begin{array}{l}\text { DSS- colitis } \\
1 \alpha, 25(\mathrm{OH})_{2}-19 \text {-nor- } \\
14,20 \text {-bisepi-23-yne- } \\
\text { vitamin D3 } \\
\text { (TX527) }\end{array}$ & $\begin{array}{l}\text { Histological examination; } \\
\text { measurement of transcript levels } \\
\text { of cytokines (IL-1, IL- } 6 \text {, IFN- } \gamma \text {, } \\
\text { and TNF- } \alpha \text { ) }\end{array}$ & $\begin{array}{l}\text { TX527 reduced "clinical" disease } \\
\text { scores and attenuated histological } \\
\text { scores, downregulation of transcript } \\
\text { levels of inflammatory cytokines }\end{array}$ \\
\hline
\end{tabular}

$\begin{array}{llll}\text { Ooi et al. } & \text { C57BL/6 mice } & \\ {[100]} & 2013 & \text { Cyp KO } & 1,25(\mathrm{OH})_{2} \mathrm{D}_{3} \text { p.o. } \\ & & \text { VDR KO }\end{array}$

DSS colitis; characterization of gut microbiota, and gut macrophages; E-cadherin expression

Lower expression of $\mathrm{E}$ cadherin and tolerogenic macrophages

Less beneficial microbiota in KO mice Vitamin D treatment ameliorates colitis and reduces Helicobacteraceae

VDR KO: colitis evaluation, pyrosequencing for microbiota, Paneth cells, lysozyme production, autophagy $\operatorname{MEF}\left(\mathrm{VDR}^{-/-} \mathrm{VDR}^{+-} \mathrm{VDR}^{+/+}\right.$) Bacteroides (B. fragilis), and and VDR knockdown in SKCO15 decreased BUT-producing bacteria; with evaluation of ATG16L1 and less and abnormal Paneth cells and

Conditional VDR $\mathrm{KO}$ and IL-10 KO mice

Wu et al. [21] 2014 DSS-colitis cells: MEF, SKCO15, HCT116 human tissue LC3B proteins

DSS colitis BUT feeding in IL-10 $\mathrm{KO}$

IL-10 KO: VDR and ATG16L1

expression with or w/o BUT feeding

Human tissue (UC, inflamed versus normal) VDR, ATG16L1, Bacteroides concentration (FISH)

HCT116 and HIEC: VDR expression with and w/o incubation with BUT
Tao et al. [102]
2014 C57BL/6 mice
TNBS-colitis Vitamin D sufficient or deficient diet
At week 14, assessment of ECM and total collagen production, together with determination in isolated colonic SEMF, of expression of VDR, $\alpha$-SMA, and Collagen I in normal SEMF
Histological scoring, ECM, and collagen production in the colon reduced in vitamin D supplemented mice; in SEMF decreased levels of TGF- $\beta 1$, Smad-3, p-Smad3, and Collagen I and induced VDR expression and decreased TGF- $\beta 1$-induced $\alpha$-SMA and Collagen I expression 
TABle 3: Continued.

\begin{tabular}{|c|c|c|c|c|c|}
\hline Author & Year & Species/cells & Investigational agent & Methodology & Main findings \\
\hline $\begin{array}{l}\text { Assa et al. } \\
{[101]}\end{array}$ & 2015 & $\begin{array}{l}\text { Caco cells } \\
\text { C57BL/ } 6 \text { mice }\end{array}$ & $\begin{array}{l}\text { DSS- colitis } \\
\text { Vitamin D sufficient } \\
\text { or deficient diet } \\
1,25(\mathrm{OH})_{2} \mathrm{D}_{3} \text { for Caco }\end{array}$ & $\begin{array}{l}\text { Caco cells incubated with or w/o } \\
1,25(\mathrm{OH})_{2} \mathrm{D}_{3} \text { challenged with } \\
\text { AIEC } \\
\text { C57BL/6 mice on normal or low } \\
1,25(\mathrm{OH})_{2} \mathrm{D}_{3} \text { diet infected with } \\
\text { AIEC }\end{array}$ & $\begin{array}{l}1,25(\mathrm{OH})_{2} \mathrm{D}_{3} \text { protects Caco cells } \\
\text { against AIEC induced loss of TER } \\
\text { and TJ protein redistribution } \\
1,25(\mathrm{OH})_{2} \mathrm{D}_{3} \text { reduces DSS colitis and } \\
\text { AIEC invasion } \\
\text { low vitamin D diet and DSS colitis } \\
\text { increased Bacteroides }\end{array}$ \\
\hline \multicolumn{6}{|c|}{ In vivo and ex vivo studies in IBD patients } \\
\hline $\begin{array}{l}\text { Stio et al. } \\
{[105]}\end{array}$ & 2007 & $4 \mathrm{CD}$ and $4 \mathrm{HC}$ & $\begin{array}{l}\text { TX } 527 \\
{[19-\text {-nor-14,20-bisepi- }} \\
\left.23 \text {-yne- } 1,25(\mathrm{OH})_{2} \mathrm{D}_{3}\right] \\
\text { Vitamin D analogue }\end{array}$ & $\begin{array}{l}\text { Single-center, ex vivo study; } \\
\text { experimental study on PBMC of } \\
\text { CD patients }\end{array}$ & $\begin{array}{l}\text { TX } 527 \text { inhibits TNF- } \alpha \text { mediated } \\
\text { effects on PBMC and the activation of } \\
\text { NF- } \kappa \text { B; its action is mediated by VDR }\end{array}$ \\
\hline $\begin{array}{l}\text { Miheller et al. } \\
\text { [107] }\end{array}$ & 2009 & $37 \mathrm{CD}$ & $\begin{array}{l}\text { Group A treated with } \\
\text { aVD versus group B } \\
\text { treated with pVD }\end{array}$ & $\begin{array}{l}\text { Single-center study; evaluation of } \\
\text { bone parameters and CDAI, CRP, } \\
\text { and SIBDQ after 6, 12, } 52 \text { weeks }\end{array}$ & $\begin{array}{l}\text { In aVD, after } 6 \text { weeks (but not at } 52 \\
\text { weeks) a significant reduction of } \\
\text { CDAI, IBDQ, and CRP together with } \\
\text { a significant change of bone } \\
\text { parameters }\end{array}$ \\
\hline $\begin{array}{l}\text { Ardizzone et } \\
\text { al. [103] }\end{array}$ & 2009 & $9 \mathrm{UC}, 8 \mathrm{CD}$ & $1,25(\mathrm{OH})_{2} \mathrm{D}_{3}$ & $\begin{array}{l}\text { Single-center ex vivo study; } \\
\text { PBMC with or without calcitriol; } \\
\text { determination of TNF- } \alpha \text {, IFN- } \gamma \text {, } \\
\text { IL-2, and IL-10 }\end{array}$ & $\begin{array}{l}\text { In UC PBMC } 1,25(\mathrm{OH})_{2} \mathrm{D}_{3} \text { reduced } \\
\text { IFN- } \gamma \text { and enhanced IL-10 } \\
\text { production } \\
\text { In CD PBMC } 1,25(\mathrm{OH})_{2} \mathrm{D}_{3} \text { reduced } \\
\text { TNF- } \alpha \text { production }\end{array}$ \\
\hline $\begin{array}{l}\text { Jørgensen et } \\
\text { al. [108] }\end{array}$ & 2010 & $94 \mathrm{CD}$ & $\begin{array}{l}\text { Vitamin D3 versus } \\
\text { placebo }\end{array}$ & $\begin{array}{l}\text { Multi-center randomized } \\
\text { double-blind placebo-controlled } \\
\text { study; } \\
1200 \text { IU vit D3/day or placebo; } \\
\text { estimation of clinical relapse rate }\end{array}$ & $\begin{array}{l}\text { Vit. D3 significantly increased } \\
\text { serum vit. D levels, but the decrease } \\
\text { of relapse was not significant ( } 13 \% \\
\text { versus } 29 \%, P=0.06)\end{array}$ \\
\hline $\begin{array}{l}\text { Bendix- } \\
\text { Struve et al. } \\
{[104]}\end{array}$ & 2010 & $108 \mathrm{CD}$ & $\begin{array}{l}\text { Vitamin D3 versus } \\
\text { placebo }\end{array}$ & $\begin{array}{l}\text { Randomized, placebo-controlled, } \\
\text { clinical trial } \\
\text { After } 0,36 \text {, and } 52 \text { weeks, PBMC } \\
\text { tested in } 10 \text { patients treated with } \\
\text { Vitamin D3 (1200 IU/day) and in } \\
10 \text { patients treated with placebo } \\
\text { for cytokine production and } \\
\text { proliferation }\end{array}$ & $\begin{array}{l}\text { Vit. D3 treatment of CD patients } \\
\text { increased the IL- } 6 \text { levels and enhance } \\
\text { the CD4 }{ }^{+} \text {T-cell proliferation }\end{array}$ \\
\hline $\begin{array}{l}\text { Laverny et al. } \\
\text { [98] }\end{array}$ & 2010 & $22 \mathrm{CD}, 21 \mathrm{UC}$ & $\begin{array}{l}1 \alpha, 25(\mathrm{OH})_{2} \text {-16-ene- } \\
20 \text {-cyclopropyl- } \\
\text { vitamin D3 } \\
(\text { BXL-62) }\end{array}$ & $\begin{array}{l}\text { Ex vivo preparations of PBMC } \\
\text { (+LPS) and (CD2/CD } 28 \\
\text { activated)-LPMCs incubated } \\
\text { with or without BXL- } 62 \text {. } \\
\text { Determination of mRNA and } \\
\text { protein concentrations of TNF- } \alpha \text {, } \\
\text { IL-12/23p } 40 \text {, IL- } 6 \text {, and IFN- } \gamma\end{array}$ & $\begin{array}{l}\text { Higher anti-inflammatory potency } \\
\text { compared to } 1,25(\mathrm{OH})_{2} \mathrm{D}_{3} \\
\text { demonstrated by the significantly } \\
\text { more potent inhibition in PBMC and } \\
\text { in LPMCs of the proinflammatory } \\
\text { cytokines TNF- } \alpha \text {, IL-12/23p } 40 \text {, IL- } 6 \text {, } \\
\text { and IFN- } \gamma\end{array}$ \\
\hline $\begin{array}{l}\text { Yang et al. } \\
{[109]}\end{array}$ & 2013 & $18 \mathrm{CD}$ & Vitamin D3 & $\begin{array}{l}\text { Open-label prospective clinical } \\
\text { trial over } 24 \text { weeks, multi-center } \\
\text { study; vitamin D3 at } 1000 \mathrm{IU} / \text { day; } \\
\text { dose increase every two week of } \\
1000 \mathrm{IU} / \text { day up to } 5000 \mathrm{IU} / \text { day to } \\
\text { achieve serum } \\
25(\mathrm{OH}) \mathrm{D}_{3}>40 \mathrm{ng} / \mathrm{mL}\end{array}$ & $\begin{array}{l}\text { Vit. D3 supplementation significantly } \\
\text { raised serum } 25(\mathrm{OH}) \mathrm{D}_{3} \text {, reduced } \\
\text { CDAI scores, and improved IBDQ } \\
\text { scores }\end{array}$ \\
\hline $\begin{array}{l}\text { Bartels et al. } \\
{[106]}\end{array}$ & 2014 & $10 \mathrm{CD}$ & Vitamin D3 & $\begin{array}{l}\text { Single-center study, oral vitamin } \\
\text { D supplementation (or placebo) } \\
\text { and assessment of maturation } \\
\text { marker expression and cytokine } \\
\text { production of monocyte-derived } \\
\text { dendritic cells }\end{array}$ & $\begin{array}{l}\text { Dendritic cells from vitamin } \\
\text { supplemented CD patients exhibited } \\
\text { reduced expression of CD } 80 \text { and } \\
\text { reduced production of the cytokines } \\
\text { IL-10, IL-1 } \beta \text {, and IL- } 6\end{array}$ \\
\hline
\end{tabular}


TABLE 3: Continued.

\begin{tabular}{|c|c|c|c|c|c|}
\hline Author & Year & Species/cells & Investigational agent & Methodology & Main findings \\
\hline $\begin{array}{l}\text { Ham et al. } \\
\text { [93] }\end{array}$ & 2014 & PBMC & $\begin{array}{l}\text { Incubation of } \mathrm{CD}^{+} \\
\text {with vit D } 50 \mathrm{nM}\end{array}$ & $\begin{array}{l}\text { Determination of } \mathrm{CD} 25^{+} \text {and } \\
\text { CD } 39^{+} \text {cells }\end{array}$ & $\begin{array}{l}\text { 3-fold increase of } \mathrm{CD} 25^{+} \text {cells, CD } 39^{+} \\
\text {unchanged }\end{array}$ \\
\hline
\end{tabular}

CD: Crohn's disease; UC: ulcerative colitis; HC: healthy controls; vit: vitamin; p.o.: per os; GI: gastrointestinal; KO: knock-out; TNBS: 2,4,6-trinitrobenzene sulfonic acid; i.p.: intraperitoneal; DSS: dextran sodium sulfate; $25(\mathrm{OH}) \mathrm{D}$ : 25 -hydroxycholecalciferol; $1,25(\mathrm{OH})_{2} \mathrm{D}_{3}$ : 1,25-dihydroxycholecalciferol; vitamin D3 (vit D3): cholecalciferol; VDR: vitamin D receptor; MEF: mouse embryonic fibroblasts; AIEC: adherent-invasive Escherichia coli; TER: transepithelial electrical resistance; TJ: tight-junction; aVD: active vitamin $\mathrm{D}\left(1,25(\mathrm{OH})_{2} \mathrm{D}_{3}\right)$; pVD: plain vitamin $\mathrm{D}(25(\mathrm{OH})$ vitamin D); CDAI: Crohn's disease activity index; CRP: C-reactive protein; SIBDQ: Short IBD questionnaire; PBMC: peripheral blood mononuclear cells; LPS, lipopolysaccharide; LPMCs: lamina propria mononuclear cells; IBDQ: IBD questionnaire; IL: interleukin; Cyp: Cyp27b1 gene; IFN: interferon; TNF: tumor necrosis factor; BUT butyrate; SEMF: subepithelial myofibroblasts; ECM: extracellular matrix; $\alpha$-SMA: alpha smooth muscle actin; FISH: fluorescent in situ hybridization; HIEC: human intestinal epithelial cells; ATG16L1: autophagy related 16-like 1 (S. cerevisiae); LC3B: autophagy-related protein LC3B; SKCO15: human colorectal adenocarcinoma cells; HCT116: human colon cancer cell.

The latter is a protein involved in autophagy, and its genetic variants are well known as risk factors for $\mathrm{CD}$. In this model, an increase of E. coli and Bacteroides, together with a decrease of butyrate producing bacteria was reported. Supplementing butyrate to IL-10 KO mice reverses reduced VDR and ATG16L1 expression. Similar results, that is, an increased expression of VDR and ATG16L1, were obtained incubating several cell lines with butyrate [21].

Finally, a reduction of intestinal fibrosis, assessed by production of extracellular matrix and total collagen, was seen in mice with TNBS colitis on a vitamin supplemented diet compared to mice fed a vitamin D deficient diet [102]. Moreover, in isolated subepithelial myofibroblasts from the colon, a vitamin D sufficient diet reduced concentrations of TGF- $\beta 1$, Smad 3, p-Smad 3, and collagen I. It was concluded that preventive vitamin $\mathrm{D}$ administration reduces fibrosis inhibiting the VDR-mediated TGF- $\beta 1 /$ Smad 3 pathway.

In the above studies, in various types of spontaneous or chemically induced colitis and in several cell lines, vitamin $\mathrm{D}$ and synthetic agonists have been shown to reduce colitis severity and intestinal fibrosis. Vitamin D hypovitaminosis or knocking down Cyp27b1 or VDR had the opposite results. Interestingly, these latter conditions were all associated with changes of the intestinal microbiota.

\section{Therapeutic Studies in Human Ex Vivo Preparations}

In an ex vivo study on PBMC obtained from IBD patients and incubated in the presence of $1,25(\mathrm{OH})_{2} \mathrm{D}_{3}$, a reduction of interferon- (IFN-) $\gamma$ and an increase of IL-10 production were observed in PBMC from UC patients whereas in CD the production of TNF- $\alpha$ were reduced [103]. The effect of orally administered vitamin D3 on monocyte-depleted PBMC from vitamin D3-treated (1200 IU vitamin D daily over 1 year) versus placebo-treated patients was investigated [104]. CD4 ${ }^{+}$ T-cell proliferation and T-cell cytokine production were assessed. IL- 6 production in vitamin $\mathrm{D}_{3}$-treated patients increased, whereas TNF- $\alpha$, IFN- $\gamma$, and IL- 4 did not. No change was observed for IL-10 and the percentage of the $\mathrm{CD}^{+}, \mathrm{CD} 25^{+}$, and Foxp $3^{+}$regulatory $\mathrm{T}$ cells compared to placebo. The amount of proliferating $\mathrm{CD}^{+} \mathrm{T}$ cells was significantly increased (from $41 \%$ to $56 \%$ ) in the vitamin-Dtreated group.
Another ex vivo study employed the vitamin $\mathrm{D}$ analogue (19-nor-14,20-bisepi-23-yne-1,25(OH) ${ }_{2} \mathrm{D}_{3}$; TX 527). This analogue significantly inhibited $\mathrm{PBMC}$ proliferation and TNF- $\alpha$ release in CD and HC [105]. The increase of VDR protein levels after incubation with TX 527 was higher in CD compared with HC. Moreover, in PBMC of both, HC and CD, stimulated with TNF- $\alpha$, a decrease in nuclear NF- $\kappa$ B protein levels together with an increase in cytoplasmic IKB- $\alpha$ levels were observed pointing to an inhibition of TNF- $\alpha$ induced effects on PBMC exerted by the vitamin D analogue.

The effect of the vitamin receptor agonist BXL-62 on PBMC from $\mathrm{CD}$ and $\mathrm{UC}$ patients and lamina propria mononuclear cells (LPMC) obtained from biopsies of two $\mathrm{CD}$ (ileum) and two UC (colon) patients was investigated [98]. After incubation, in LPS-stimulated PBMC and in activated LPMC from IBD patients, BXL-62 significantly inhibited, with a significantly higher potency compared with $1,25(\mathrm{OH})_{2} \mathrm{D}_{3}$, TNF- $\alpha$, IL- 6 , and IL-12/23p40 transcription and cytokine concentrations measured in culture supernatants without differences between CD and UC.

In PBMC of CD patients, expression of the CYP27B1 gene, that is, the gene that encodes the enzyme that converts $25(\mathrm{OH}) \mathrm{D}_{3}$ to $1,25(\mathrm{OH})_{2} \mathrm{D}_{3}$, and that of the VDR gene was investigated, showing a higher expression in active compared to inactive disease [93]. Moreover, $\mathrm{CD}^{+} \mathrm{T}$ cells incubated in the presence of vitamin D showed a threefold increase of $\mathrm{CD} 25^{+}$cells.

Finally, the effect of oral vitamin D supplementation on the maturation and cytokine production of monocytederived dendritic cells of CD patients was studied [106]. Compared to placebo-treated CD patients, vitamin D supplementation led to reduced CD80 expression in LPS-stimulated dendritic cells together with reduced production of IL-10, IL$1 \beta$, and IL-6.

\section{Therapeutic Studies in Human IBD}

There are only few studies with vitamin $\mathrm{D}$ addressing the clinical course of IBD (Table 3). In one of these studies, the effect of supplementation of the active form of vitamin $\mathrm{D}$ $1,25(\mathrm{OH})_{2} \mathrm{D}_{3}\left(\mathrm{aVD}, 1000 \mathrm{IU} 1.25(\mathrm{OH})_{2} \mathrm{D}_{3}\right.$ daily) versus the plain vitamin $\mathrm{D} 25(\mathrm{OH}) \mathrm{D}(\mathrm{pVD} ; 2 \times 0.25 \mu \mathrm{g}$ alphacalcidiol daily) was investigated in $\mathrm{CD}$ patients in clinical remission $($ CDAI < 150) [107]. Both groups received oral calcium 
supplementation (1000 mg/day). At 6 weeks, the mean CDAI and IBDQ scores, as well as the CRP concentrations, decreased in the aVD-treated group, but not in the pVDtreated group. These differences between the groups however disappeared by week 52 . Serum calcium concentrations did not change at any time point. Jørgensen et al. [108] performed a randomized double-blind placebo-controlled multicenter study to assess the benefit of vitamin D3 treatment in CD. They included 94 CD patients in clinical $($ CDAI $<150)$ and biochemical remission, randomized to receive $1200 \mathrm{IU}$ of vitamin D3 + $1200 \mathrm{mg}$ of calcium or $1200 \mathrm{mg}$ of calcium alone. During 1-year follow-up, serum $25(\mathrm{OH}) \mathrm{D}_{3}$ levels increased significantly in vitamin $\mathrm{D}$-supplemented patients, on average from 27 to $38 \mathrm{ng} / \mathrm{mL}$, but free serum calcium did not change. The relapse rate (defined as increase of CDAI $>70$ over baseline and CDAI $\geq 150$ ) was not significantly lowered. Adjustment for the use of azathioprine and smoking resulted in minor changes of the risk estimate. However, the authors concluded that vitamin $\mathrm{D}$ might be effective in $\mathrm{CD}$ but claimed the need for larger studies.

In an uncontrolled study, 18 active CD patients were initially treated with $1000 \mathrm{IU}$ vitamin D daily over 2 weeks. Thereafter, the dose was escalated (to a maximum of $5000 \mathrm{IU}$ ) until a serum concentration of $40 \mathrm{ng} / \mathrm{mL}$ of $25(\mathrm{OH}) \mathrm{D}_{3}$ was reached [109]. After 24 weeks, a significant reduction of the CDAI and an improvement of the IBDQ score were observed. No differences were observed for CRP, erythrocyte sedimentation rate (ESR), TNF- $\alpha$, IL-17, IL-10, and vascular endothelial growth factor (VEGF). Data on serum calcium levels were not reported.

In this last paragraph, the therapeutic effects of vitamin $\mathrm{D}$ supplementation on disease activity mainly given to patients in remission yielded modest results; the daily administered dose ranged in these studies between 1000 and 5000 IU, with an increase of serum vitamin $\mathrm{D}$ levels but apparently without hypercalcemia.

\section{Conclusions}

Literature data highlighting the importance of vitamin D in different aspects of immune regulation, for example, in chronic immune-mediated diseases and cancer, suggest considering this metabolite not simply as a vitamin involved in bone and calcium homeostasis but as an autocrine mediator with an active role in numerous physiological processes, particularly in the innate immune system. Since most studies concerning the calcium status in IBD yielded contradictory data, in the most recent literature, the discussion has focused on the possible role of vitamin $\mathrm{D}$ as a risk factor for the onset and evolution of gut inflammation. The potential role of $25(\mathrm{OH})_{2} \mathrm{D}$ as negative acute phase reactant has yet to be proven in IBD but may explain its frequently reduced levels in active disease. Besides lower vitamin $\mathrm{D}$ levels due to reduced UV exposure, genetic induced loss of function of VDR may contribute to defects involving vitamin $\mathrm{D}$ pathways. It has been shown in VDR KO animals that this deletion profoundly alters innate immune response and the gut microbiota. Further studies in this field are needed to provide more insight in the link between vitamin D/VDR and bowel inflammation.

Simple vitamin D supplementation does not seem to lead to significant improvement of the clinical course of IBD but may be indicated for a subset of patients. Vitamin D synthetic analogues of vitamin $\mathrm{D}$ seem to be more promising, at least in animal studies and in ex vivo experiments.

\section{Conflict of Interests}

The authors declare that there is no conflict of interests regarding the publication of this paper.

\section{Acknowledgment}

The authors wish to thank Trays Ricciardi for language editing.

\section{References}

[1] G. Jones, S. A. Strugnell, and H. F. DeLuca, "Current understanding of the molecular actions of vitamin D," Physiological Reviews, vol. 78, no. 4, pp. 1193-1231, 1998.

[2] N. Narula and J. K. Marshall, "Management of inflammatory bowel disease with vitamin D: beyond bone health," Journal of Crohn's \& Colitis, vol. 6, no. 4, pp. 397-404, 2012.

[3] M. F. Holick, T. C. Chen, Z. Lu, and E. Sauter, "Vitamin D and skin physiology: a D-lightful story," Journal of Bone and Mineral Research, vol. 22, no. 2, pp. V28-V33, 2007.

[4] F. Baeke, E. V. Etten, C. Gysemans, L. Overbergh, and C. Mathieu, "Vitamin D signaling in immune-mediated disorders: evolving insights and therapeutic opportunities," Molecular Aspects of Medicine, vol. 29, no. 6, pp. 376-387, 2008.

[5] J. W. Pike and M. B. Meyer, "The vitamin D receptor: new paradigms for the regulation of gene expression by 1,25 dihydroxyvitamin D3," Rheumatic Disease Clinics of North America, vol. 38, no. 1, pp. 13-27, 2012.

[6] M. Raman, A. N. Milestone, J. R. F. Walters, A. L. Har, and S. Ghosh, "Vitamin D and gastrointestinal diseases: inflammatory bowel disease and colorectal cancer," Therapeutic Advances in Gastroenterology, vol. 4, no. 1, pp. 49-62, 2011.

[7] R. F. Chun, P. T. Liu, R. L. Modlin, J. S. Adams, and M. Hewison, "Impact of vitamin D on immune function: lessons learned from genome-wide analysis," Frontiers in Physiology, vol. 5, article 151, 15 pages, 2014.

[8] J. Sun, "Vitamin D and mucosal immune function," Current Opinion in Gastroenterology, vol. 26, no. 6, pp. 591-595, 2010.

[9] J. Chen, D. Bruce, and M. T. Cantorna, "Vitamin D receptor expression controls proliferation of naïve $\mathrm{CD}^{+} \mathrm{T}$ cells and development of CD8 mediated gastrointestinal inflammation," BMC Immunology, vol. 15, no. 6, pp. 1-11, 2014.

[10] H. Kühne, A. Schutkowski, S. Weinholz et al., "Vitamin D receptor regulates intestinal proteins involved in cell proliferation, migration and stress response," Lipids in Health and Disease, vol. 13, article 51, 2014.

[11] E. van Etten and C. Mathieu, "Immunoregulation by 1,25dihydroxyvitamin D3: basic concepts," The Journal of Steroid Biochemistry and Molecular Biology, vol. 97, no. 1-2, pp. 93-101, 2005. 
[12] J. Tang, R. Zhou, D. Luger et al., "Calcitriol suppresses antiretinal autoimmunity through inhibitory effects on the Th17 effector response," Journal of Immunology, vol. 182, no. 8, pp. 4624-4632, 2009.

[13] L. E. Jeffery, F. Burke, M. Mura et al., "1,25-Dihydroxyvitamin D3 and IL-2 combine to inhibit T cell production of inflammatory cytokines and promote development of regulatory $\mathrm{T}$ cells expressing CTLA-4 and FoxP3," Journal of Immunology, vol. 183, no. 9, pp. 5458-5467, 2009.

[14] M. R. Haussler, C. A. Haussler, G. K. Whitfield et al., "The nuclear vitamin $\mathrm{D}$ receptor controls the expression of genes encoding factors which feed the 'Fountain of Youth' to mediate healthful aging," The Journal of Steroid Biochemistry and Molecular Biology, vol. 121, no. 1-2, pp. 88-97, 2010.

[15] J. N. Artaza, F. Sirad, M. G. Ferrini, and K. C. Norris, " $1,25(\mathrm{OH})_{2}$ vitamin $\mathrm{D}_{3}$ inhibits cell proliferation by promoting cell cycle arrest without inducing apoptosis and modifies cell morphology of mesenchymal multipotent cells," The Journal of Steroid Biochemistry and Molecular Biology, vol. 119, no. 1-2, pp. 73-83, 2010.

[16] M. G. Bischof, K. Redlich, C. Schiller et al., "Growth inhibitory effects on human colon adenocarcinoma-derived Caco-2 cells and calcemic potential of $1 \alpha, 25$ - dihydroxyvitamin D3 analogs: structure-function relationships," Journal of Pharmacology and Experimental Therapeutics, vol. 275, no. 3, pp. 1254-1260, 1995.

[17] H. S. Cross, M. Pavelka, J. Slavik, and M. Peterlik, "Growth control of human colon cancer cells by vitamin D and calcium in vitro," Journal of the National Cancer Institute, vol. 84, no. 17, pp. 1355-1362, 1992.

[18] J. P. Hugot, M. Chamaillard, H. Zouali et al., "Association of NOD2 leucine-rich repeat variants with susceptibility to Crohn's disease," Nature, vol. 411, no. 6837, pp. 599-603, 2001.

[19] N. Inohara, Y. Ogura, A. Fontalba et al., "Host recognition of bacterial muramyl dipeptide mediated through NOD2. Implications for Crohn's disease," The Journal of Biological Chemistry, vol. 278, no. 8, pp. 5509-5512, 2003.

[20] T. T. Wang, B. Dabbas, D. Laperriere et al., "Direct and indirect induction by 1,25-dihydroxyvitamin D3 of the NOD2/CARD15defensin beta 2 innate immune pathway defective in Crohn disease," The Journal of Biological Chemistry, vol. 285, no. 4, pp. 2227-2231, 2010.

[21] S. Wu, Y. G. Zhang, R. Lu et al., "Intestinal epithelial vitamin D receptor deletion leads to defective autophagy in colitis," Gut, 2014.

[22] M. Verway, M. A. Behr, and J. H. White, "Vitamin D, NOD2, autophagy and Crohn's disease," Expert Review of Clinical Immunology, vol. 6, no. 4, pp. 505-508, 2010.

[23] J. D. Simmons, C. Mullighan, K. I. Welsh, and D. P. Jewell, "Vitamin D receptor gene polymorphism: association with Crohn's disease susceptibility," Gut, vol. 47, no. 2, pp. 211-214, 2000.

[24] K. Martin, M. Radlmayr, R. Borchers, M. Heinzlmann, and C. Folwaczny, "Candidate genes colocalized to linkage regions in inflammatory bowel disease," Digestion, vol. 66, no. 2, pp. 121126, 2002.

[25] K. Köstner, N. Denzer, C. S. L. Müller, R. Klein, W. Tilgen, and J. Reichrath, "The relevance of Vitamin D Receptor (VDR) gene polymorphisms for cancer: a review of the literature," Anticancer Research, vol. 29, no. 9, pp. 3511-3536, 2009.

[26] Y. Xu, B. He, Y. Pan et al., "Systematic review and meta-analysis on vitamin D receptor polymorphisms and cancer risk," Tumour Biology, vol. 35, no. 5, pp. 4153-4169, 2014.
[27] K. Tizaoui, A. Berraies, B. Hamdi, W. Kaabachi, K. Hamzaoui, and A. Hamzaoui, "Association of vitamin d receptor gene polymorphisms with asthma risk: systematic review and updated meta-analysis of case-control studies," Lung, vol. 192, no. 6, pp. 955-965, 2014.

[28] D. Santoro, D. Caccamo, G. Gagliostro et al., "Vitamin D metabolism and activity as well as genetic variants of the vitamin D receptor (VDR) in chronic kidney disease patients," Journal of Nephrology, vol. 26, no. 4, pp. 636-644, 2013.

[29] D. J. Hughes, R. McManus, P. Neary, C. O’Morain, and M. O'Sullivan, "Common variation in the vitamin D receptor gene and risk of inflammatory bowel disease in an Irish case-control study," European Journal of Gastroenterology \& Hepatology, vol. 23, no. 9, pp. 807-812, 2011.

[30] W. Pluskiewicz, J. Zdrzałek, and D. Karasek, "Spine bone mineral density and VDR polymorphism in subjects with ulcerative colitis," Journal of Bone and Mineral Metabolism, vol. 27, no. 5, pp. 567-573, 2009.

[31] F. H. Pei, Y. J. Wang, S. L. Gao et al., "Vitamin D receptor gene polymorphism and ulcerative colitis susceptibility in Han Chinese," Journal of Digestive Diseases, vol. 12, no. 2, pp. 90-98, 2011.

[32] S. L. Xia, L. Q. Yu, H. Chen et al., "Association of vitamin D receptor gene polymorphisms with the susceptibility to ulcerative colitis in patients from Southeast China," Journal of Receptors and Signal Transduction, 2014.

[33] Y. Y. Luo, X. L. Shu, H. Zhao, J. D. Yu, M. Ma, and J. Chen, "Association between vitamin D receptor gene polymorphisms and pediatric Crohn's disease in China: A study based on gene sequencing," Zhongguo Dang Dai Er Ke Za Zhi, vol. 15, no. 11, pp. 1006-1008, 2013.

[34] C. L. Noble, J. McCullough, W. Ho et al., "Low body mass not vitamin D receptor polymorphisms predict osteoporosis in patients with inflammatory bowel disease," Alimentary Pharmacology \& Therapeutics, vol. 27, no. 7, pp. 588-596, 2008.

[35] R. W. Bentley, D. Keown, T. R. Merriman et al., "Vitamin $\mathrm{D}$ receptor gene polymorphism associated with inflammatory bowel disease in New Zealand males," Alimentary Pharmacology and Therapeutics, vol. 33, no. 7, pp. 855-856, 2011.

[36] R. Dresner-Pollak, Z. Ackerman, R. Eliakim, A. Karban, Y. Chowers, and H. H. Fidder, "The BsmI vitamin D receptor gene polymorphism is associated with ulcerative colitis in Jewish Ashkenazi patients," Genetic Testing, vol. 8, no. 4, pp. 417-420, 2004.

[37] N. Naderi, A. Farnood, M. Habibi et al., "Association of vitamin D receptor gene polymorphisms in Iranian patients with inflammatory bowel disease," Journal of Gastroenterology and Hepatology, vol. 23, no. 12, pp. 1816-1822, 2008.

[38] L.-N. Xue, K.-Q. Xu, W. Zhang, Q. Wang, J. Wu, and X.-Y. Wang, "Associations between vitamin D receptor polymorphisms and susceptibility to ulcerative colitis and Crohn's disease: a metaanalysis," Inflammatory Bowel Diseases, vol. 19, no. 1, pp. 54-60, 2013.

[39] L. Wang, Z. T. Wang, J. J. Hu, R. Fan, J. Zhou, and J. Zhong, "Polymorphisms of the vitamin D receptor gene and the risk of inflammatory bowel disease: a meta-analysis," Genetics and Molecular Research, vol. 13, no. 2, pp. 2598-2610, 2014.

[40] A. Y. O. M. Carvalho, K. S. Bishop, D. Y. Han et al., "The role of vitamin D level and related single nucleotide polymorphisms in Crohn's disease," Nutrients, vol. 5, no. 10, pp. 3898-3909, 2013. 
[41] G. Jones and G. Stewart, "Association of PHF11 polymorphisms with asthma and allergy," Thorax, vol. 65, no. 7, pp. 659-660, 2010.

[42] J. J. Eloranta, C. Wenger, J. Mwinyi et al., "Association of a common vitamin D-binding protein polymorphism with inflammatory bowel disease," Pharmacogenetics and Genomics, vol. 21, no. 9, pp. 559-564, 2011.

[43] A. Sonnenberg, H. Ehms, G. E. Sonnenberg, and G. Strohmeyer, "25-Hydroxycholecalciferol serum levels in patients with Crohn's disease," Acta Hepato-Gastroenterologica, vol. 24, no. 4, pp. 293-295, 1977.

[44] T. Nic Suibhne, G. Cox, M. Healy, C. O'Morain, and M. O'Sullivan, "Vitamin D deficiency in Crohn's disease: prevalence, risk factors and supplement use in an outpatient setting," Journal of Crohn's \& Colitis, vol. 6, no. 2, pp. 182-188, 2012.

[45] S. Ardizzone, S. Bollani, P. Bettica, M. Bevilacqua, P. Molteni, and G. B. Porro, "Altered bone metabolism in inflammatory bowel disease: there is a difference between Crohn's disease and ulcerative colitis," Journal of Internal Medicine, vol. 247, no. 1, pp. 63-70, 2000.

[46] M. Tajika, A. Matsuura, T. Nakamura et al., "Risk factors for vitamin D deficiency in patients with Crohn's disease," Journal of Gastroenterology, vol. 39, no. 6, pp. 527-533, 2004.

[47] M. T. Abreu, Y. Kantorovich, E. A. Vasiliauskas et al., "Measurement of vitamin D levels in inflammatory bowel disease patients reveals a subset of Crohn's disease patients with elevated 1,25dihydroxyvitamin D and low bone mineral density," Gut, vol. 53, no. 8, pp. 1129-1136, 2004.

[48] J. R. de Bruyn, R. van Heeckeren, C. Y. Ponsioen et al., "Vitamin D deficiency in Crohn's disease and healthy controls: a prospective case-control study in the Netherlands," Journal of Crohn's and Colitis, vol. 8, no. 10, pp. 1267-1273, 2014.

[49] L. E. Veit, L. Maranda, J. Fong, and B. U. Nwosu, "The vitamin D status in inflammatory bowel disease," PLoS ONE, vol. 9, no. 7, Article ID e101583, 2014.

[50] A. D. Harries, R. Brown, R. V. Heatley, L. A. Williams, S. Woodhead, and J. Rhodes, "Vitamin D status in Crohn's disease: association with nutrition and disease activity," Gut, vol. 26, no. 11, pp. 1197-1203, 1985.

[51] M. Rudnicki, A. Frølich, and I. Transbøl, "Inappropriate hypercalcitriolemia in ileum-resected patients with Crohn's disease," Mineral and Electrolyte Metabolism, vol. 18, no. 1, pp. 52-55, 1992.

[52] A. J. Joseph, B. George, A. B. Pulimood, M. S. Seshadri, and A. Chacko, "25 (OH) vitamin D level in Crohn's disease: association with sun exposure \& disease activity," Indian Journal of Medical Research, vol. 130, no. 2, pp. 133-137, 2009.

[53] D. McCarthy, P. Duggan, M. O'Brien et al., "Seasonality of vitamin D status and bone turnover in patients with Crohn's disease," Alimentary Pharmacology \& Therapeutics, vol. 21, no. 9, pp. 1073-1083, 2005.

[54] W. El-Matary, S. Sikora, and D. Spady, "Bone mineral density, vitamin $\mathrm{D}$, and disease activity in children newly diagnosed with inflammatory bowel disease," Digestive Diseases and Sciences, vol. 56, no. 3, pp. 825-829, 2011.

[55] J. Silvennoinen, "Relationships between vitamin D, parathyroid hormone and bone mineral density in inflammatory bowel disease," Journal of Internal Medicine, vol. 239, no. 2, pp. 131-137, 1996.

[56] J. Gilman, F. Shanahan, and K. D. Cashman, "Altered levels of biochemical indices of bone turnover and bone-related vitamins in patients with Crohn's disease and ulcerative colitis," Alimentary Pharmacology \& Therapeutics, vol. 23, no. 7, pp. 1007-1016, 2006.

[57] H. N. de Souza, F. L. Lora, C. A. M. Kulak, N. C. P. Mañas, H. M. B. Amarante, and V. Z. C. Borba, "Low levels of 25hydroxyvitamin $\mathrm{D}$ (25OHD) in patients with inflammatory bowel disease and its correlation with bone mineral density," Arquivos Brasileiros de Endocrinologia e Metabologia, vol. 52, no. 4, pp. 684-691, 2008.

[58] W. D. Leslie, N. Miller, L. Rogala, and C. N. Bernstein, "Vitamin $\mathrm{D}$ status and bone density in recently diagnosed inflammatory bowel disease: the Manitoba IBD Cohort Study," American Journal of Gastroenterology, vol. 103, no. 6, pp. 1451-1459, 2008.

[59] A. Ulitsky, A. N. Ananthakrishnan, A. Naik et al., "Vitamin $\mathrm{D}$ deficiency in patients with inflammatory bowel disease: association with disease activity and quality of life," Journal of Parenteral and Enteral Nutrition, vol. 35, no. 3, pp. 308-316, 2011.

[60] V. Hassan, S. Hassan, P. Seyed-Javad et al., "Association between serum $25(\mathrm{OH})$ vitamin D concentrations and inflammatory bowel diseases (IBDS) activity," Medical Journal of Malaysia, vol. 68, no. 1, pp. 34-38, 2013.

[61] R. H. Alkhouri, H. Hashmi, R. D. Baker, D. Gelfond, and S. S. Baker, "Vitamin and mineral status in patients with inflammatory bowel disease," Journal of Pediatric Gastroenterology and Nutrition, vol. 56, no. 1, pp. 89-92, 2013.

[62] H. M. Pappa, C. M. Gordon, T. M. Saslowsky et al., "Vitamin $\mathrm{D}$ status in children and young adults with inflammatory bowel disease," Pediatrics, vol. 118, no. 5, pp. 1950-1961, 2006.

[63] J. Jahnsen, J. A. Falch, P. Mowinckel, and E. Aadland, "Vitamin D status, parathyroid hormone and bone mineral density in patients with inflammatory bowel disease," Scandinavian Journal of Gastroenterology, vol. 37, no. 2, pp. 192-199, 2002.

[64] A. Kuwabara, K. Tanaka, N. Tsugawa et al., "High prevalence of vitamin $\mathrm{K}$ and $\mathrm{D}$ deficiency and decreased BMD in inflammatory bowel disease," Osteoporosis International, vol. 20, no. 6, pp. 935-942, 2009.

[65] Y. Ezzat and K. Hamdy, "The frequency of low bone mineral density and its associated risk factors in patients with inflammatory bowel diseases," International Journal of Rheumatic Diseases, vol. 13, no. 3, pp. 259-265, 2010.

[66] A. Atia, R. Murthy, B. A. Bailey et al., "Vitamin D Status in Veterans with inflammatory bowel disease: relationship to Health care costs and services," Military Medicine, vol. 176, no. 6, pp. 711-714, 2011.

[67] I. Hessov, L. Mosekilde, F. Melsen et al., "Osteopenia with normal vitamin D metabolites after small-bowel resection for Crohn's disease," Scandinavian Journal of Gastroenterology, vol. 19, no. 5, pp. 691-696, 1984.

[68] S. Nakajima, H. Iijima, S. Egawa et al., "Association of vitamin K deficiency with bone metabolism and clinical disease activity in inflammatory bowel disease," Nutrition, vol. 27, no. 10, pp. 10231028, 2011.

[69] S. Laakso, H. Valta, M. Verkasalo, S. Toiviainen-Salo, H. Viljakainen, and O. Mäkitie, "Impaired bone health in inflammatory bowel disease: a case-control study in 80 pediatric patients," Calcified Tissue International, vol. 91, no. 2, pp. 121-130, 2012.

[70] R. H. Driscoll Jr., S. C. Meredith, M. Sitrin, and I. H. Rosenberg, "Vitamin D deficiency and bone disease in patients with Crohn's disease," Gastroenterology, vol. 83, no. 6, pp. 1252-1258, 1982.

[71] H. Vogelsang, R. Schöfl, W. Tillinger, P. Ferenci, and A. Gangl, "25-Hydroxyvitamin D absorption in patients with Crohn's 
disease and with pancreatic insufficiency," Wiener Klinische Wochenschrift, vol. 109, no. 17, pp. 678-682, 1997.

[72] E. J. Schoon, M. C. A. Müller, C. Vermeer, L. J. Schurgers, R.-J. M. Brummer, and R. W. Stockbrügger, "Low serum and bone vitamin $\mathrm{K}$ status in patients with longstanding Crohn's disease: another pathogenetic factor of osteoporosis in Crohn's disease?" Gut, vol. 48, no. 4, pp. 473-477, 2001.

[73] K. V. Haderslev, P. B. Jeppesen, H. A. Sorensen, P. B. Mortensen, and M. Staun, "Vitamin D status and measurements of markers of bone metabolism in patients with small intestinal resection," Gut, vol. 52, no. 5, pp. 653-658, 2003.

[74] J. Gilman, F. Shanahan, and K. D. Cashman, "Determinants of vitamin D status in adult Crohn's disease patients, with particular emphasis on supplemental vitamin D use," European Journal of Clinical Nutrition, vol. 60, no. 7, pp. 889-896, 2006.

[75] A. D. Levin, V. Wadhera, S. T. Leach et al., "Vitamin D deficiency in children with inflammatory bowel disease," Digestive Diseases and Sciences, vol. 56, no. 3, pp. 830-836, 2011.

[76] G. P. Kini, B. Young, P. Herbison, and M. Schultz, "Does seasonal level of serum $25-\mathrm{OH}$ vitamin D correlate with the activity of Crohn's disease?" New Zealand Medical Journal, vol. 127, no. 1394, pp. 51-59, 2014.

[77] F. A. Farraye, H. Nimitphong, A. Stucchi et al., "Use of a novel vitamin D bioavailability test demonstrates that vitamin $\mathrm{D}$ absorption is decreased in patients with quiescent Crohn's disease," Inflammatory Bowel Diseases, vol. 17, no. 10, pp. 21162121, 2011.

[78] T. A. Sentongo, E. J. Semaeo, N. Stettler, D. A. Piccoli, V. A. Stallings, and B. S. Zemel, "Vitamin D status in children, adolescents, and young adults with Crohn disease," The American Journal of Clinical Nutrition, vol. 76, no. 5, pp. 1077-1081, 2002.

[79] J. S. Siffledeen, K. Siminoski, H. Steinhart, G. Greenberg, and R. N. Fedorak, "The frequency of vitamin D deficiency in adults with Crohn's disease," Canadian Journal of Gastroenterology, vol. 17, no. 8, pp. 473-478, 2003.

[80] H. M. Pappa, E. J. Langereis, R. J. Grand, and C. M. Gordon, "Prevalence and risk factors for hypovitaminosis D in young patients with inflammatory bowel disease," Journal of Pediatric Gastroenterology and Nutrition, vol. 53, no. 4, pp. 361-364, 2011.

[81] A. N. Ananthakrishnan, A. Cagan, V. S. Gainer et al., "Normalization of plasma 25-hydroxy vitamin $\mathrm{D}$ is associated with reduced risk of surgery in Crohn's disease," Inflammatory Bowel Diseases, vol. 19, no. 9, pp. 1921-1927, 2013.

[82] T. Hlavaty, A. Krajcovicova, T. Koller et al., "Higher vitamin D serum concentration increases health related quality of life in patients with inflammatory bowel diseases," World Journal of Gastroenterology, vol. 20, no. 42, pp. 15787-15796, 2014.

[83] L. Peyrin-Biroulet, A. Oussalah, and M.-A. Bigard, "Crohn's disease: the hot hypothesis," Medical Hypotheses, vol. 73, no. 1, pp. 94-96, 2009.

[84] J. R. de Bruyn, R. van Heeckeren, C. Y. Ponsioen et al., "Vitamin D deficiency in Crohn's disease and healthy controls: a prospective case-control study in the Netherlands," Journal of Crohn's \& Colitis, vol. 8, no. 10, pp. 1267-1273, 2014.

[85] V. Nerich, P. Jantchou, M.-C. Boutron-Ruault et al., "Low exposure to sunlight is a risk factor for Crohn's disease," Alimentary Pharmacology and Therapeutics, vol. 33, no. 8, pp. 940-945, 2011.

[86] P. Jantchou, F. Clavel-Chapelon, A. Racine, M. Kvaskoff, F. Carbonnel, and M.-C. Boutron-Ruault, "High residential sun exposure is associated with a low risk of incident Crohn's disease in the prospective E3N cohort," Inflammatory Bowel Diseases, vol. 20, no. 1, pp. 75-81, 2014.

[87] B. N. Limketkai, T. M. Bayless, S. R. Brant, and S. M. Hutfless, "Lower regional and temporal ultraviolet exposure is associated with increased rates and severity of inflammatory bowel disease hospitalisation," Alimentary Pharmacology \& Therapeutics, vol. 40, no. 5, pp. 508-517, 2014.

[88] S. M. Govani, P. D. R. Higgins, R. W. Stidham, S. J. Montain, and A. K. Waljee, "Increased ultraviolet light exposure is associated with reduced risk of inpatient surgery among patients with Crohn's disease," Journal of Crohn's and Colitis, vol. 9, no. 1, pp. 77-81, 2015.

[89] A. N. Ananthakrishnan, H. Khalili, L. M. Higuchi et al., "Higher predicted vitamin $\mathrm{D}$ status is associated with reduced risk of crohn's disease," Gastroenterology, vol. 142, no. 3, pp. 482-489, 2012.

[90] M. Garg, O. Rosella, J. S. Lubel, and P. R. Gibson, "Association of circulating vitamin $\mathrm{D}$ concentrations with intestinal but not systemic inflammation in inflammatory bowel disease," Inflammatory Bowel Diseases, vol. 19, no. 12, pp. 2634-2643, 2013.

[91] A. N. Ananthakrishnan, A. Cagan, V. S. Gainer et al., "Higher plasma vitamin $\mathrm{D}$ is associated with reduced risk of Clostridium difficile infection in patients with inflammatory bowel diseases," Alimentary Pharmacology and Therapeutics, vol. 39, no. 10, pp. 1136-1142, 2014.

[92] Z. A. Zator, S. M. Cantu, G. G. Konijeti et al., "Pretreatment 25hydroxyvitamin D levels and durability of anti-tumor necrosis factor- $\alpha$ therapy in inflammatory bowel diseases," Journal of Parenteral and Enteral Nutrition, vol. 38, no. 3, pp. 385-391, 2014.

[93] M. Ham, M. S. Longhi, C. Lahiff, A. Cheifetz, S. Robson, and A. C. Moss, "Vitamin D levels in adults with Crohn's disease are responsive to disease activity and treatment," Inflammatory Bowel Diseases, vol. 20, no. 5, pp. 856-860, 2014.

[94] D. Reid, B. J. Toole, S. Knox et al., "The relation between acute changes in the systemic inflammatory response and plasma 25-hydroxyvitamin D concentrations after elective knee arthroplasty," The American Journal of Clinical Nutrition, vol. 93, no. 5, pp. 1006-1011, 2011.

[95] J. L. Waldron, H. L. Ashby, M. P. Cornes et al., "Vitamin D: a negative acute phase reactant," Journal of Clinical Pathology, vol. 66, no. 7, pp. 620-622, 2013.

[96] M. T. Cantorna, C. Munsick, C. Bemiss, and B. D. Mahon, "1,25Dihydroxycholecalciferol prevents and ameliorates symptoms of experimental murine inflammatory bowel disease," Journal of Nutrition, vol. 130, no. 11, pp. 2648-2652, 2000.

[97] C. Daniel, H. H. Radeke, N. A. Sartory et al., "The new low calcemic vitamin D analog 22-ene-25-oxa-vitamin D prominently ameliorates Thelper cell type 1-mediated colitis in mice," Journal of Pharmacology and Experimental Therapeutics, vol. 319, no. 2, pp. 622-631, 2006.

[98] G. Laverny, G. Penna, S. Vetrano et al., "Efficacy of a potent and safe vitamin $\mathrm{D}$ receptor agonist for the treatment of inflammatory bowel disease," Immunology Letters, vol. 131, no. 1, pp. 49-58, 2010.

[99] L. Verlinden, C. Leyssens, I. Beullens et al., “The vitamin D analog TX527 ameliorates disease symptoms in a chemically induced model of inflammatory bowel disease," The Journal of Steroid Biochemistry and Molecular Biology, vol. 136, no. 1, pp. 107-111, 2013.

[100] J. H. Ooi, Y. Li, C. J. Rogers, and M. T. Cantorna, "Vitamin D regulates the gut microbiome and protects mice from dextran 
sodium sulfate-induced coliti," Journal of Nutrition, vol. 143, no. 10, pp. 1679-1686, 2013.

[101] A. Assa, L. Vong, L. J. Pinnell et al., "Vitamin D deficiency predisposes to adherent-invasive Escherichia coli-induced barrier dysfunction and experimental colonic injury," Inflammatory Bowel Diseases, vol. 21, no. 2, pp. 297-306, 2015.

[102] Q. Tao, B. Wang, Y. Zheng, X. Jiang, Z. Pan, and J. Ren, "Vitamin D prevents the intestinal fibrosis via induction of vitamin $\mathrm{D}$ receptor and inhibition of transforming growth factor-betal/smad3 pathway," Digestive Diseases and Sciences, 2014.

[103] S. Ardizzone, A. Cassinotti, D. Trabattoni et al., "Immunomodulatory effects of 1,25-dihydroxyvitamin D3 on Th1/Th2 cytokines in inflammatory bowel disease: an in vitro study," International Journal of Immunopathology and Pharmacology, vol. 22, no. 1, pp. 63-71, 2009.

[104] M. Bendix-Struve, L. E. Bartels, J. Agnholt, A. Dige, S. P. Jørgensen, and J. F. Dahlerup, "Vitamin D3 treatment of Crohns disease patients increases stimulated T cell IL- 6 production and proliferation," Alimentary Pharmacology \& Therapeutics, vol. 32, no. 11-12, pp. 1364-1372, 2010.

[105] M. Stio, M. Martinesi, S. Bruni et al., "The Vitamin D analogue TX 527 blocks NF-kappaB activation in peripheral blood mononuclear cells of patients with Crohn's disease," Journal of Steroid Biochemistry and Molecular Biology, vol. 103, no. 1, pp. 51-60, 2007.

[106] L. E. Bartels, M. Bendix, C. L. Hvas et al., "Oral vitamin D3 supplementation reduces monocyte-derived dendritic cell maturation and cytokine production in Crohn's disease patients," Inflammopharmacology, vol. 22, no. 2, pp. 95-103, 2014.

[107] P. Miheller, G. Muzes, I. Hritz et al., "Comparison of the effects of 1,25 dihydroxyvitamin $\mathrm{D}$ and 25 hydroxyvitamin $\mathrm{D}$ on bone pathology and disease activity in Crohn's disease patients," Inflammatory Bowel Diseases, vol. 15, no. 11, pp. 1656-1662, 2009.

[108] S. P. Jørgensen, J. Agnholt, H. Glerup et al., "Clinical trial: vitamin D3 treatment in Crohn's disease-a randomized doubleblind placebo-controlled study," Alimentary Pharmacology and Therapeutics, vol. 32, no. 3, pp. 377-383, 2010.

[109] L. Yang, V. Weaver, J. P. Smith, S. Bingaman, T. J. Hartman, and M. T. Cantorna, "Therapeutic effect of vitamin D supplementation in a pilot study of Crohn's patients," Clinical and Translational Gastroenterology, vol. 4, article e33, 2013. 


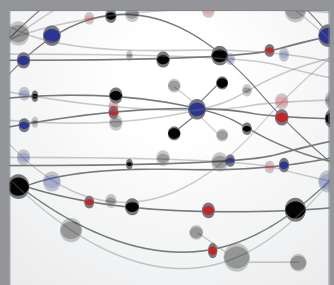

The Scientific World Journal
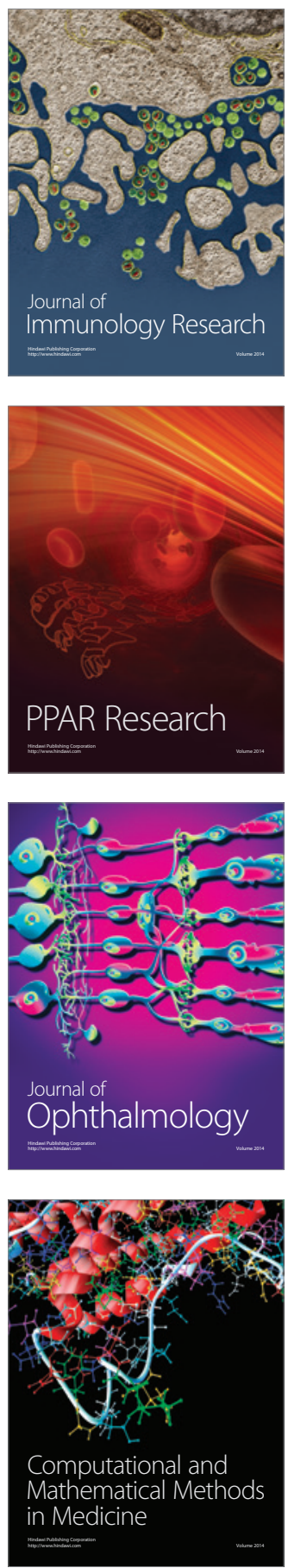

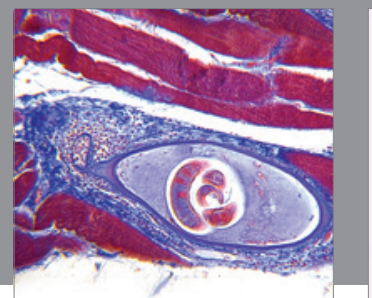

Gastroenterology

Research and Practice
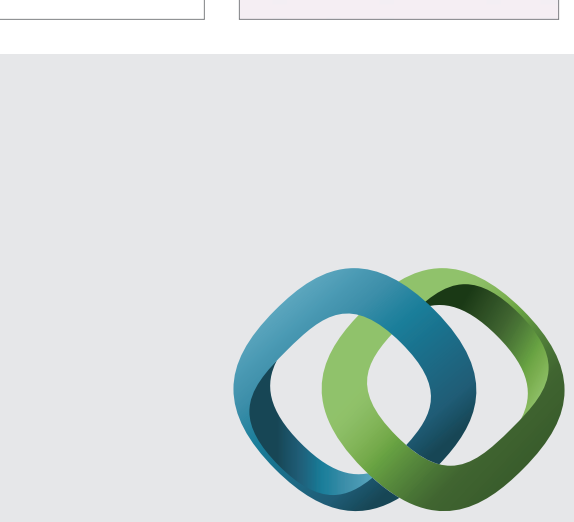

\section{Hindawi}

Submit your manuscripts at

http://www.hindawi.com
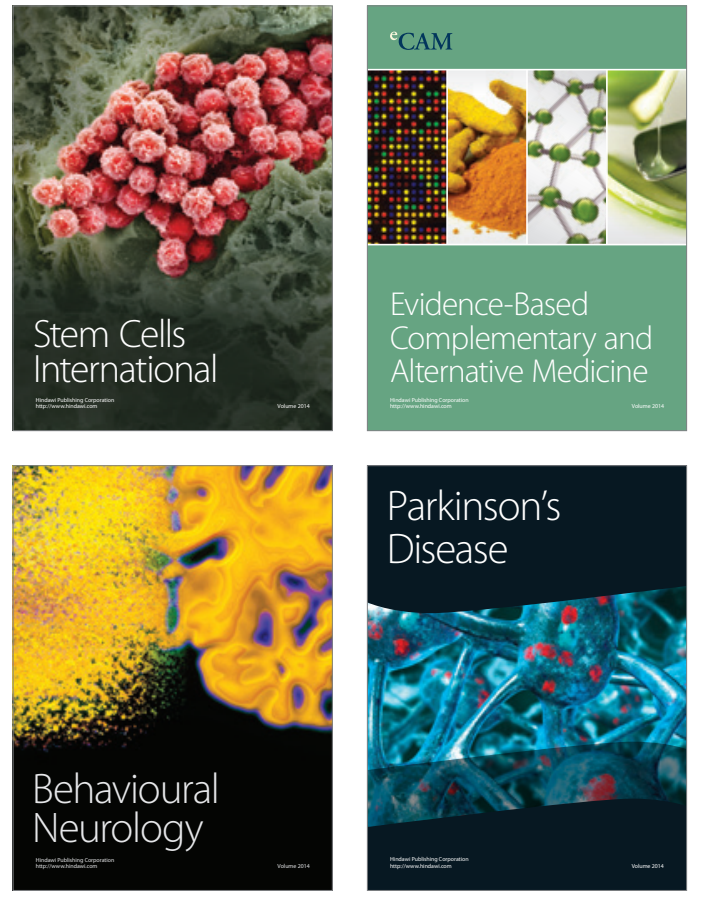
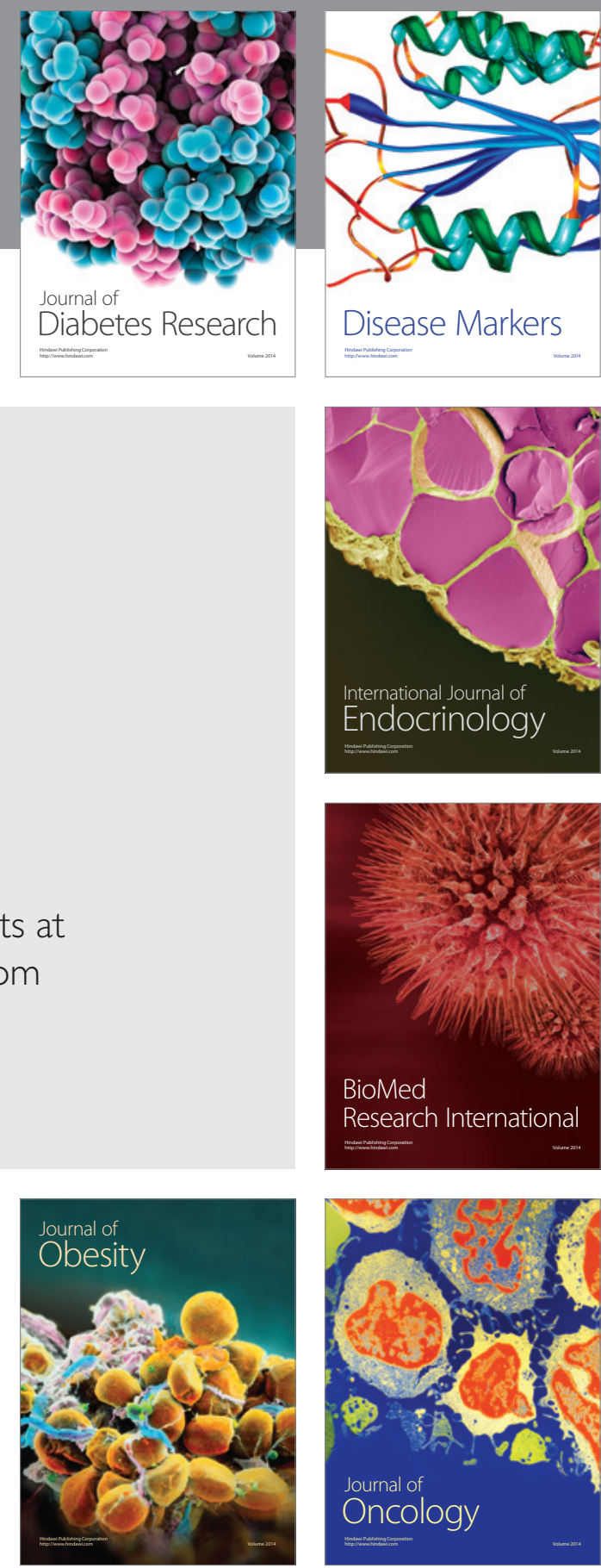

Disease Markers
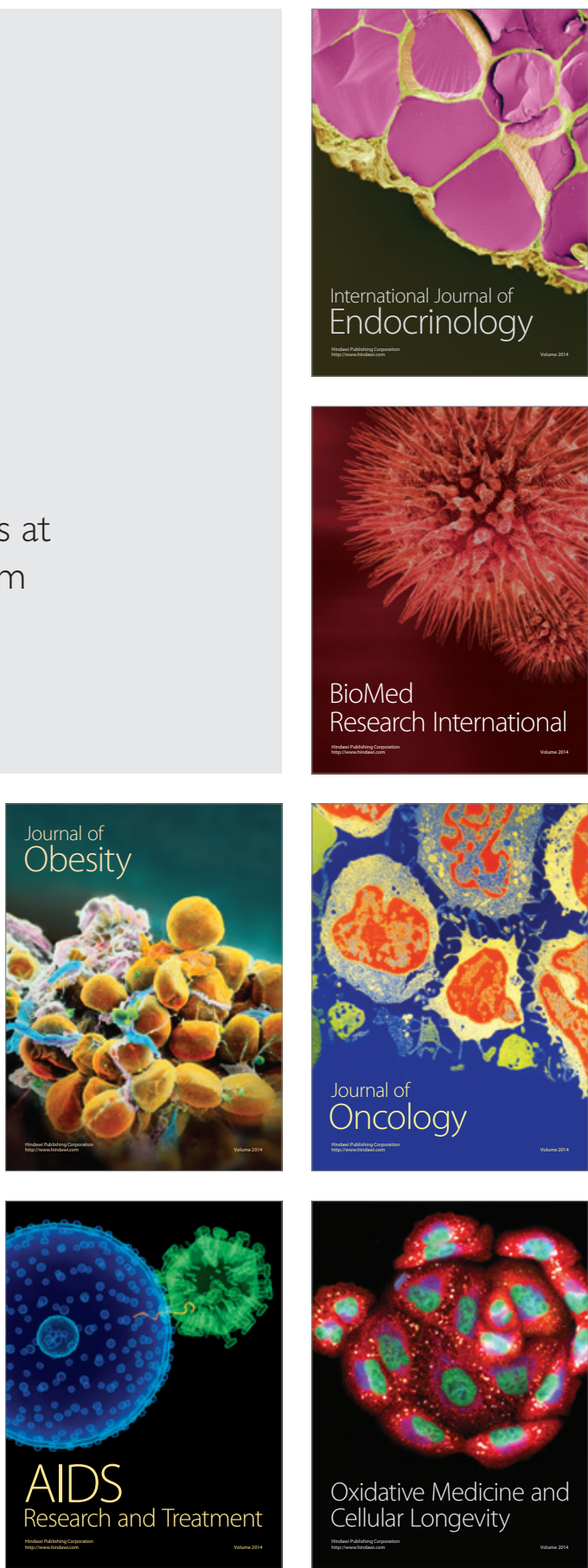